\title{
DFI-seq identification of environment- specific gene expression in uropathogenic Escherichia coli
}

\author{
Michelle Madelung ${ }^{1}$, Tina Kronborg ${ }^{1}$, Thomas Koed Doktor ${ }^{1}$, Carsten Struve ${ }^{2}$, Karen Angeliki Krogfelt ${ }^{2}$
} and Jakob Møller-Jensen ${ }^{1 *}$

\begin{abstract}
Background: During infection of the urinary tract, uropathogenic Escherichia coli (UPEC) are exposed to different environments, such as human urine and the intracellular environments of bladder epithelial cells. Each environment elicits a distinct bacterial environment-specific transcriptional response. We combined differential fluorescence induction (DFI) with next-generation sequencing, collectively termed DFI-seq, to identify differentially expressed genes in UPEC strain UTI89 during growth in human urine and bladder cells.

Results: DFI-seq eliminates the need for iterative cell sorting of the bacterial library and yields a genome-wide view of gene expression. By analysing the gene expression of UPEC in human urine we found that genes involved in amino acid biosynthesis were upregulated. Deletion mutants lacking genes involved in arginine biosynthesis were outcompeted by the wild type during growth in human urine and inhibited in their ability to invade or proliferate in the J82 bladder epithelial cell line. Furthermore, DFl-seq was used to identify genes involved in invasion of J82 bladder epithelial cells. 56 genes were identified to be differentially expressed of which almost $60 \%$ encoded hypothetical proteins. One such gene UT189_C5139, displayed increased adhesion and invasion of J82 cells when deleted from UPEC strain UTI89.

Conclusions: We demonstrate the usefulness of DFI-seq for identification of genes required for optimal growth of UPEC in human urine, as well as potential virulence genes upregulated during infection of bladder cell culture. DFIseq holds potential for the study of bacterial gene expression in live-animal infection systems. By linking fitness genes, such as those genes involved in amino acid biosynthesis, to virulence, this study contributes to our understanding of UPEC pathophysiology.
\end{abstract}

Keywords: DFI, NGS, UPEC, Amino acid biosynthesis, Virulence, UTI

\section{Background}

Urinary tract infections (UTIs) are one of the most common infectious diseases and approximately $40-50 \%$ of women will experience a UTI in the course of their lifetime. Symptoms can range from mild irritative voiding, to bacteraemia, sepsis, and even death [1]. The economic burden is high and in 2010 it was estimated that the annual direct and indirect cost of UTIs in the United States was $\$ 2.3$ billion. A wide range of bacterial species

\footnotetext{
* Correspondence: jakobm@bmb.sdu.dk

'Department of Biochemistry and Molecular Biology, University of Southern

Denmark, Campusvej 55, 5230 Odense M, Denmark

Full list of author information is available at the end of the article
}

including Klebsiella spp., Pseudomonas aeruginosa and Streptococcus agalactiae are capable of causing UTIs. The majority of infections are however caused by uropathogenic E. coli (UPEC), which is responsible for $75 \%$ of all community-acquired UTIs [2].

UPEC bacteria encounter histologically distinct environments during their ascent through the urinary tract of humans. Colonization of the periurethral area is followed by bacterial entry into the bladder via the urethra. UPEC grow and persist in the bladder despite the constant urine flow they experience. During acute infection of the bladder, UPEC infect bladder epithelial cells (BECs) to initiate biofilm-like intracellular bacterial 
community (IBC) formation [3]. The acute infection ends with superficial BECs being exfoliated due to inflammation brought on by the invading bacteria [4]. At the same time, IBCs mature and the intracellular bacterial population display phenotypic variation; some cells become motile and rod-shaped while others turn into filaments more than 50 micrometer in length. At this stage the bacteria burst out into the lumen of the bladder [5]. The inflammation brought on by UPEC leads to recruitment of polymorphonuclear neutrophils (PMNs) into the bladder, which eliminates the majority of the released rod shaped UPEC. Filamentous bacteria resist clearance by the PMNs however, and are capable of reverting back to rod shape to initiate a second round of infection and IBC formation [6-8]. Bladder cell exfoliation renders underlying layers of undifferentiated tissue accessible to bacterial invasion. Inside the deeper tissue layers, UPEC can form quiescent intracellular reservoirs (QIRs), consisting of a single or few non-dividing bacteria. These QIRs may constitute a reservoir for recurrent UTIs [5, 9]. From the bladder, UPEC can further ascend the ureters to the kidneys where they trigger inflammation. Finally, in severe cases, UPEC may traverse into the bloodstream causing life-threatening sepsis [10].

Several virulence- or fitness-associated factors have been identified to be involved in UPEC infection of the urinary tract. Among these factors are adhesive fimbriae: type-1 fimbriae which bind to the urothelium of the bladder during acute infection [11], F9/Yde/Fml pili which are involved in specific binding to inflamed bladder tissue [12], and P fimbriae that are important during kidney infections [13]. Additional factors include the K1 capsule, which has a role in facilitating intracellular UPEC proliferation and IBC formation [14], the surface adhesin antigen 43 , an autotransporter protein that promotes autoaggregation and is expressed by the bacteria embedded in the polysaccharide matrix of IBCs [3], iron acquisition genes necessary for bacterial growth in the iron limited environment of the host [15], and the toxins $\alpha-$ Hemolysin $[16,17]$, cytotoxic necrotizing factor type 1 [17] and secreted autotransporter toxin [18], all affecting the host urothelium during infection.

Recently, a redefinition of the concept of bacterial virulence was proposed [19]. It has been shown that UPEC fitness in the urinary tract depends on the tricarboxylic acid cycle and gluconeogenesis [20]. Moreover, peptide transporters have been shown to be induced in urine and to be required for fitness during infection [20]. Hence, virulence is determined by the sum of required metabolic pathways, the traditional virulence determinants, and upregulated transport systems and other indispensable functions [19]. In this study, we focus on environment-specific gene expression to further our understanding of UPEC pathophysiology. The experiments are centred on identification of genes involved in environment-specific adaptation, growth, and persistence during urine exposure in the bladder, and invasion and intracellular proliferation in the superficial cells of the bladder.

We combined the differential fluorescence induction (DFI) technique [21] with next-generation sequencing (NGS) to identify UPEC genes that are differentially expressed in response to human urine and growth inside the BEC line J82.

In DFI, a promoter trap library is created by inserting chromosomal DNA fragments from the bacteria of interest into a plasmid containing a promoterless $g f p$ gene, encoding green fluorescent protein (GFP). The plasmids are then transformed into the bacteria of interest. The resulting promoter trap library is subjected to the conditions under investigation and to a reference condition. By performing consecutive fluorescence-activated cell sorting (FACS) rounds, activated promoters can be identified.

Combining DFI with NGS (termed DFI-seq) is expected to enable a comprehensive and genome-wide view of differential gene expression compared to DFI alone [22], as the DFI-seq principle, as outlined in Fig. 1, eliminates the need for consecutive sorting of the bacterial library, thereby limiting potential biases associated herewith.

As with DFI, the bacterial library is exposed to two different environments- the environment under investigation, and a reference environment used to induce the expression of housekeeping genes. In DFI-seq however, the library is grown in parallel in the two respective environments, followed by isolation of fluorescent bacteria. The enriched genomic DNA contained in each promoter trap plasmid is then sequenced and mapped to the genome. By comparing the number of reads from each environment it is possible to identify promoters that are differentially expressed during growth in the two environments.

By applying DFI-seq on UPEC cultured in human urine we identify genes encoding hypothetical proteins as well as genes involved in amino acid biosynthesis to be differentially expressed in human urine. Five genes involved in arginine biosynthesis were found to be induced during growth in human urine. Deletion mutants of these genes exhibit low competition compared to the wild type during competition assays and demonstrated a reduced ability to invade or proliferate inside the $\mathrm{BEC}$ line J82. DFI-seq was further applied to UPEC infecting the BEC line J82 and resulted in the identification of 56 genes that were differentially expressed, including a previously uncharacterized gene UTI89_C5139, which was upregulated inside the bladder cells. Deletion of UTI89_C5139 resulted in an enhanced ability to bind and invade or proliferate inside cultured BECs. 


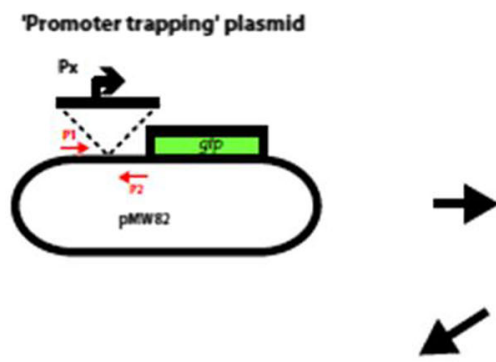

Infection of model organism / cell culture
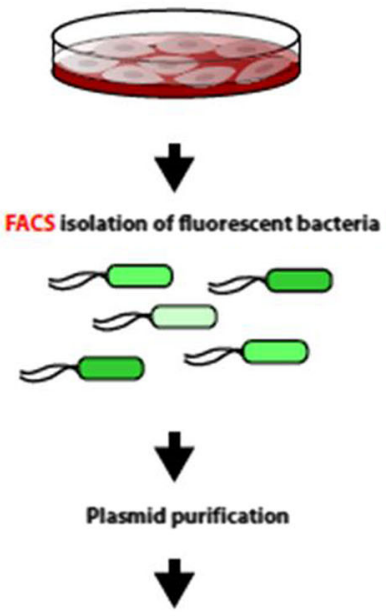

PCR amplification of promoter regions using primers P1 and P2
Promoter-Gfp fusion library
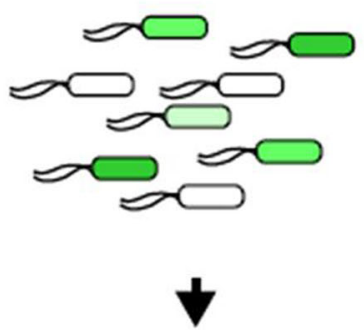

In vitro culture
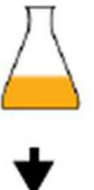

FACS isolation of fluorescent bacteria
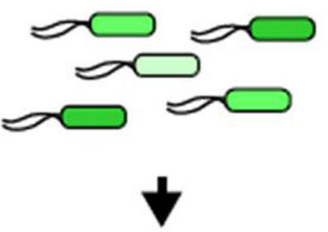

Plasmid purification

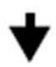

PCR amplification of promoter regions using primers $\mathrm{P1}$ and $\mathrm{P2}$

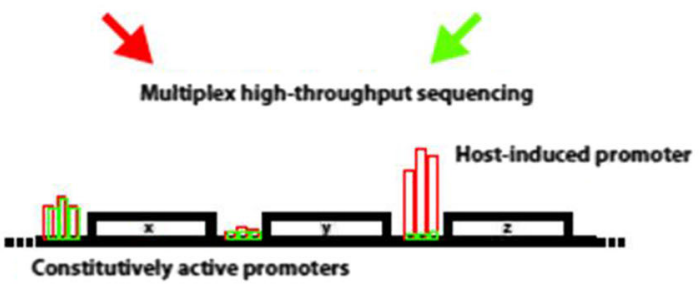

Fig. 1 A promoter trap library is created using a gfp gene as reporter. The library is transformed into the bacteria of interest. The pool of transformants is both used to infect a tissue culture model and grown in vitro. From both environments, green fluorescent bacteria are enriched using a fluorescence-activated cell sorting instrument and grown over night in vitro. From the two populations plasmids are purified and PCR is performed to amplify trapped promoters. Through next-generation sequencing, host-induced promoters can be identified by comparing promoter read counts between the two conditions

\section{Results}

\section{Identification of urine-induced genes by DFI}

Based on the physiological relevance and experimental tractability of human urine, we chose this microenvironment as the initial test condition for investigation into UPEC environment-specific gene expression.

As a reference for validation of DFI-seq, we first used the established DFI method to identify urine-induced genes in UTI89. In order to create a promoter trap library, genomic DNA from E. coli UTI89 was sheared into 500700-basepair (bp) fragments and inserted upstream of a promoterless gfp_ova fusion reporter gene [23] on a medium copy-number plasmid (pMW82). The resulting plasmid library, termed pMWLib, was transformed into commercially available highly competent $E$. coli MegaX $\mathrm{DH}_{10 \mathrm{~B}}{ }^{\mathrm{TM}} \mathrm{T}^{\mathrm{R}}$ Electrocomp ${ }^{\mathrm{TM}}$ Cells, resulting in approximately $1.4 \times 10^{5}$ independent transcriptional fusions, $80 \%$ of which carried an insert. This number corresponds to a seven-fold genome coverage [22, 24]. The plasmid DNA library was subsequently purified and used to transform $E$. coli UTI89, thereby giving rise to $4 \times 10^{6}$ independent transformants. To verify that introduction of the plasmid library had no inhibitory effect on fitness, the DFI library was cultured in Lysogeny broth (LB) and compared to wild type UTI89. Consistent with previous reports [23], no growth inhibition was observed (data not shown). 
UTI89/pMWLib was grown to mid-exponential phase in human urine followed by FACS-based enrichment of green-fluorescent bacteria. Next, the sorted bacteria were grown in LB followed by FACS enrichment of nonfluorescent bacteria. This two-step cycle was repeated to enrich for bacterial promoters that were selectively activated in human urine. After five consecutive sorts, the resulting bacteria were plated on LB medium to obtain clonal colonies. The percentage of green-fluorescent bacteria in the human urine-cultured bacterial population increased with every iteration; from 2 to 7.1 to $60.9 \%$ (Table 1).

We analysed the clonal heterogeneity of DFI-enriched bacteria by restriction fragment length polymorphism (RFLP) analysis. The RFLP patterns of 192 colonies revealed a high degree of clonal diversity (data not shown). PCR products amplified from the DNA inserts of 95 RFLP analysed colonies were therefore sequenced. The sequences could be mapped to 28 genes on the UTI89 genome using BLAST (http://blast.ncbi.nlm.nih.gov/) (Table 2).

16 genes were identified in two or more colonies. 13 genes were identified in two or more colonies containing different inserts, for details see Table 2. With the exception of three, all sequences identified in DFI mapped to regions upstream of genes.

Not all colonies could be unambiguously assigned to a unique chromosomal locus on the UTI89 genome. Sequences from four colonies each mapped upstream of two genes. The sequence from colony ID 17 mapped to a region spanning upstream of $e c n A$, the $e c n A$ coding sequence and upstream of ecnB. The sequence from colony ID 35 mapped 634 nucleotides upstream of $a s n B$ and 215 upstream of manZ. Colony ID 91 mapped 522 nucleotides upstream of UTI89_C1129 and 80 nucleotides upstream of UTI89_4885. Colony ID 41 mapped 554 nucleotides upstream of yaiM and 322 nucleotides upstream of serA.

Selected DFI-enriched colonies (marked in Bold in Table 2) were subsequently grown in human urine and
LB to confirm the urine-specific transcriptional induction. The mean GFP fluorescence from these cultures was obtained by flow cytometry analysis, and the fold increase in GFP fluorescence is shown in Table 2. 19 colonies, representing 21 gene promoters, displayed fluorescence induction in human urine. The two cultures representing the metE and metF gene promoters showed highly induced GFP expression in human urine (25.4 and 42.5-fold, respectively). 12 cultures were upregulated between 3.9 and 14.1-fold, while five cultures showed less than 3-fold increase in GFP expression. The remaining six cultures, representing seven gene promoters, displayed either an increased GFP fluorescence level in LB compared to human urine, no fluorescence in human urine, or no growth in human urine. These are most likely false-positives resulting from erroneous inclusion in the sorted population.

In order to confirm promoter induction, quantitative real time RT-PCR (RT-qPCR) analysis was employed on bacterial RNA isolated from UTI89 grown in human urine and LB. We analysed gene expression in the wildtype, testing promoter activity independent of the library clones. The region mapping to the pUTI89 plasmid, and the region mapping to the opposite stand of $y a g V$ was excluded from RT-qPCR, as GFP expression could not be verified for these regions. Of the 26 genes included in the RT-qPCR analysis, 15 genes were shown to be induced significantly in human urine whereas seven were expressed more strongly in LB compared to human urine. The four remaining genes could not be placed in either group (Fig. 2). Thus, out of 26 regions found by DFI to be differentially expressed during UTI89 growth in human urine compared to LB, 15 genes were confirmed by GFP expression analysis and RT-qPCR (Fig. 2a) to be upregulated.

\section{Identification of urine-induced genes by DFI-seq}

We moved on to perform DFI-seq on UPEC cultured in human urine. UTI89/pMWLib was grown in human urine and LB in parallel followed by FACSbased isolation of green-fluorescent bacteria from

Table 1 DFI sorting overview. Proportion of population enriched by sorting. Sort number 1, 3, and 5 enrich for green fluorescent bacteria; sort number 2 and 4 enrich for non-fluorescent bacteria

\begin{tabular}{|c|c|c|c|}
\hline Sort number & Original bacterial culture & Growth medium & $\begin{array}{l}\text { Proportion of population } \\
\text { enriched by sorting }\end{array}$ \\
\hline 1 & Original UTI89/pMWLib & Human urine & $2 \%(n=307,176)$ \\
\hline 2 & $\begin{array}{l}\text { Fluorescent bacteria isolated during the } \\
\text { 1. Sort }\end{array}$ & LB & $20.5 \%(n=1,249,036)$ \\
\hline 3 & $\begin{array}{l}\text { Non-fluorescent bacteria isolated during the } \\
\text { 2. Sort }\end{array}$ & Human urine & $7.1 \%(n=401,299)$ \\
\hline 4 & $\begin{array}{l}\text { Fluorescent bacteria isolated during the } \\
\text { 3. Sort }\end{array}$ & LB & $74.8 \%(n=1,733,294)$ \\
\hline 5 & $\begin{array}{l}\text { Non-fluorescent bacteria isolated during the } \\
\text { 4. Sort }\end{array}$ & Human urine & $60.9 \%(n=409,343)$ \\
\hline
\end{tabular}


Table 2 Sequenced inserts, gene name and protein product. UTI89 genome coordinates of identified inserts, and position relative to proximal genes. Colony identifiers are ordered in accordance to sequence start and end sites. Colonies marked in bold were used for GFP expression analysis. Differential fluorescence is reported as GFP fluorescence fold change of select UTI89/pMWLib clones grown in human urine versus LB

\begin{tabular}{|c|c|c|c|c|c|c|}
\hline Gene & Protein & $\begin{array}{l}\text { Gene } \\
\text { start }\end{array}$ & $\begin{array}{l}\text { Insert } \\
\text { sequence } \\
\text { start }\end{array}$ & $\begin{array}{l}\text { Insert } \\
\text { sequence } \\
\text { end }\end{array}$ & Colony ID & $\begin{array}{l}\text { Fold change in } \\
\text { mean GFP signal }\end{array}$ \\
\hline \multirow[t]{2}{*}{$\arg A$} & \multirow[t]{2}{*}{$\mathrm{N}$-acetylglutamate synthase } & \multirow[t]{2}{*}{3139678} & 3139160 & 3139678 & 8,57 & \multirow[t]{2}{*}{13.5} \\
\hline & & & 3139113 & 3139736 & 45 & \\
\hline \multirow[t]{2}{*}{$\arg C$} & \multirow{2}{*}{$\begin{array}{l}\mathrm{N} \text {-acetyl-gamma-glutamyl-phosphate } \\
\text { reductase }\end{array}$} & \multirow[t]{2}{*}{4439034} & 4438574 & 4439108 & 60 & \multirow[t]{2}{*}{8.2} \\
\hline & & & 4438733 & 4439183 & 84 & \\
\hline \multirow[t]{2}{*}{$\arg E$} & \multirow[t]{2}{*}{ Acetylornithine deacetylase } & \multirow[t]{2}{*}{4438919} & 4439100 & 4438541 & 4,93 & \multirow[t]{2}{*}{14.1} \\
\hline & & & 4439305 & 4438787 & 42 & \\
\hline \multirow[t]{2}{*}{$\arg G$} & \multirow[t]{2}{*}{ Argininosuccinate synthase } & \multirow[t]{2}{*}{3538472} & 3538296 & 3538904 & 51 & \multirow[t]{2}{*}{4.3} \\
\hline & & & 3538143 & 3538627 & 82 & \\
\hline arts & Arginine-binding periplasmic protein 2 & 861650 & 862067 & 861578 & 16 & 7.9 \\
\hline $\operatorname{asn} A$ & asparagine synthetase $\mathrm{A}$ & 4188023 & 4187539 & 4188150 & $1,24,38,46,49,86$ & 1.4 \\
\hline \multirow[t]{3}{*}{$a s n B$} & \multirow[t]{3}{*}{ asparagine synthetase $B$} & \multirow[t]{3}{*}{674199} & 674321 & 673791 & 30 & \multirow[t]{3}{*}{ Lower in urine } \\
\hline & & & 674541 & 673908 & 35 & \\
\hline & & & 674162 & 673571 & 72 & \\
\hline $\operatorname{manZ}$ & $\begin{array}{l}\text { PTS system mannose-specific transporter } \\
\text { subunit IID }\end{array}$ & 1930575 & 1930463 & 1930677 & 35 & Lower in urine \\
\hline ecnA & entericidin A & 4648116 & 4647814 & 4648373 & 17 & 2.1 \\
\hline$e c n B$ & entericidin B & 4648352 & & & & \\
\hline \multirow[t]{2}{*}{ ilvC } & \multirow[t]{2}{*}{ Ketol-acid reductoisomerase } & \multirow[t]{2}{*}{4218632} & 4218651 & 4219116 & 20 & \multirow[t]{2}{*}{4.5} \\
\hline & & & 4218333 & 4218799 & 83 & \\
\hline ilvG & Acetolacetate synthase 2 catalytic subunit & 4211428 & 4210930 & 4211421 & 7,10 & 13.8 \\
\hline \multirow[t]{4}{*}{ metA } & \multirow[t]{4}{*}{ Homoserine O-succinyltransferase } & 4462506 & 4462367 & 4462876 & 2 & 2.4 \\
\hline & & & 4462142 & 4462760 & 9,11 & \\
\hline & & & 4462396 & 4462910 & $\mathbf{3 4}, 52,53,66,73,79,90$ & \\
\hline & & & 4462388 & 4463001 & 81 & \\
\hline metC & Cystathionine beta-lyase & 3362694 & 3362313 & 3362827 & 76 & 2.7 \\
\hline metE & 5-methyltetrahydropteroyltriglutamate- & 4277928 & 4277452 & 4277904 & $6,26,67$ & 25.4 \\
\hline & & & 4277357 & 4277878 & $13,44,58,87$ & \\
\hline & & & 4277611 & 4278191 & 74 & \\
\hline metF & 5,10-methylenetetrahydrofolate reductase & 4416931 & 4416691 & 4417181 & $\mathbf{1 8}, 23,31$ & 42.5 \\
\hline potF & putrescine $A B C$ transporter substrate- & 854834 & 854439 & 855001 & 5 & 2.4 \\
\hline & Dinaing proteln & & 854460 & 855009 & 43 & \\
\hline $\operatorname{ser} A$ & D-3-phosphoglycerate dehydrogenase & 3236056 & 3236446 & 3236125 & 41 & 3.9 \\
\hline yaim & hypothetical protein & 395196 & 395661 & 395108 & & \\
\hline UT189_C1129 & $\begin{array}{l}\text { outer membrane heme/hemoglobin } \\
\text { receptor }\end{array}$ & 1122532 & 1122106 & 1122627 & 91 & Lower in urine \\
\hline UT189_C4885 & hypothetical protein & 4787503 & 4787381 & 4787460 & & \\
\hline yajB & ACP phosphodieterase & 439176 & 439346 & 438767 & 25 & Lower in urine \\
\hline$y b d H$ & hypothetical protein & 617328 & 617543 & 617035 & $\mathbf{3}, 15,36,54,69,85,88,92$ & 9.5 \\
\hline & & & 617447 & 617035 & 89 & \\
\hline & & & 617636 & 617023 & $21,50,56,77$ & \\
\hline & & & 617691 & 617083 & 28,78 & \\
\hline
\end{tabular}


Table 2 Sequenced inserts, gene name and protein product. UTI89 genome coordinates of identified inserts, and position relative to proximal genes. Colony identifiers are ordered in accordance to sequence start and end sites. Colonies marked in bold were used for GFP expression analysis. Differential fluorescence is reported as GFP fluorescence fold change of select UTI89/pMWLib clones grown in human urine versus LB (Continued)

\begin{tabular}{|c|c|c|c|c|c|c|}
\hline & & & 617543 & 617107 & 61 & \\
\hline \multirow[t]{2}{*}{$y b d L$} & \multirow[t]{2}{*}{ aminotransferase } & \multirow[t]{2}{*}{617488} & 617206 & 617798 & $33,37,47$ & \multirow[t]{2}{*}{5.0} \\
\hline & & & 617323 & 617815 & 62 & \\
\hline year & Hypothetical protein & 1912199 & 1912872 & 1912250 & 65 & 6.6 \\
\hline \multirow[t]{2}{*}{ yibl } & \multirow[t]{2}{*}{ Hypothetical protein } & 4027446 & 4027775 & 4027295 & $19,70,75$ & \multirow[t]{2}{*}{5.6} \\
\hline & & & 4027590 & 4027356 & 68 & \\
\hline \multirow{2}{*}{\multicolumn{2}{|c|}{$\begin{array}{l}\text { Unannotated } \\
\text { gene }\end{array}$}} & & 48649 & 49106 & $\begin{array}{l}12,14,22,27,32,39,40,48, \\
55,59,64,71,80,94,95\end{array}$ & \multirow[t]{2}{*}{ Non-fluorescent } \\
\hline & & & 48681 & 49177 & 63 & \\
\hline \multicolumn{2}{|c|}{$\begin{array}{l}\text { Opposite } \\
\text { strand of } \\
\text { yagV }\end{array}$} & & 315403 & 315898 & 29 & $\begin{array}{l}\text { Could not be } \\
\text { cultivated in urine }\end{array}$ \\
\hline
\end{tabular}

both samples. In human urine, $2 \%$ of the population was found to be fluorescent; this percentage was 8.1 in LB. We sorted 307,176 events from the human urine culture and 1,315,930 events from the LB cultured sample. Sorted populations of greenfluorescent bacteria were cultured overnight for plasmid preparation, followed by PCR amplification of the inserted DNA segments. The PCR products were subsequently fragmented into 250-400 bp segments and prepared for single-end Illumina sequencing using an in-house protocol [25].

$2,269,169$ reads from the LB-grown sample and $1,042,702$ reads from the human urine-grown sample were mapped to the UTI89 genome. The average read
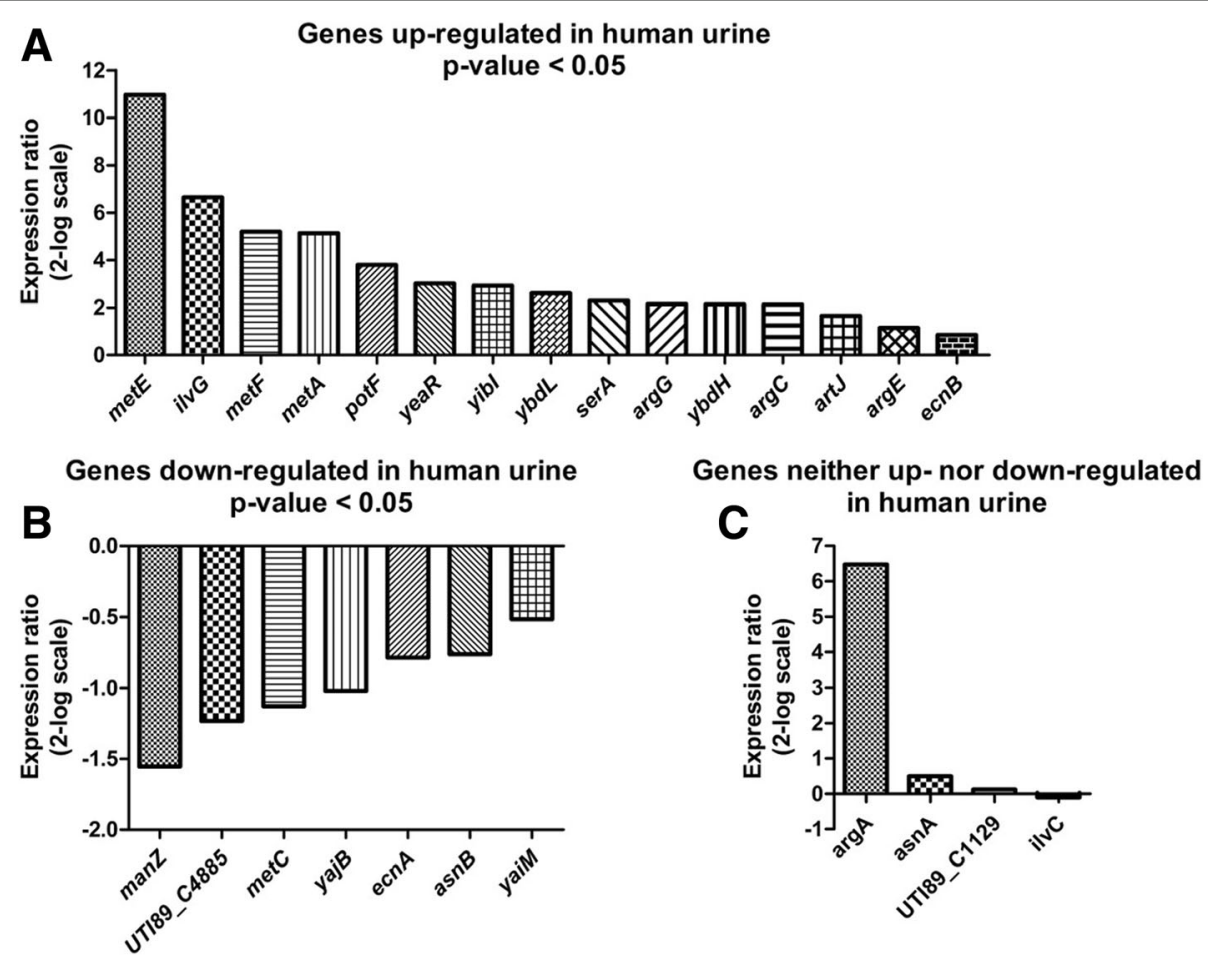

Fig. 2 RT-qPCR verification of differentially expressed genes identified by DFI. RT-qPCR was performed on bacterial RNA isolated from UTI89 grown in human urine and LB, respectively. $\mathbf{a}$ and $\mathbf{b}$ Expression ratios (log2 scale) of genes differentially expressed in human urine compared to $L B$, with $P<0.05$. $c$ Gene expression ratios (log2 scale) of uniformly expressed genes $(P>0.05)$. A pairwise fixed reallocation randomisation test was performed [45] and exact $p$-values can be found in Additional file 10: Table S1 
length was $67 \mathrm{bp}$ in both samples and 31.53\% of LB culture reads and $33.79 \%$ of the human urine culture reads uniquely mapped to the UTI89 genome. Promoters were defined as the region spanning from $300 \mathrm{bp}$ upstream of the transcription start site (TSS) to $50 \mathrm{bp}$ downstream of the TSS. Operons were defined as bookended transcripts, i.e. genes with no base pairs separating them. The number of reads mapping to a defined promoter was compared between the two growth conditions. 33 genes were identified to be upregulated in human urine compared to LB, i.e. with a positive regularized logarithm fold change (rLogFC) [26] of the genes or defined operons of at least 1.5. 31 genes were identified to be downregulated in human urine compared to LB, i.e. with a negative rLogFC of the genes or defined operons of -1.5 or less. Genes and defined operons with an absolute rLogFC of at least 1.5 are listed in Table 3 (upregulated genes) and Table 4 (downregulated genes).

The activity of identified promoters, was analysed by RT-qPCR using bacterial RNA isolated from UTI89 grown in human urine and LB, respectively. Figure 3 shows the expression ratio of all 42 genes analysed. Of

Table 3 rLogFC values for genes upregulated in human urine. BLAST results of hypothetical proteins are represented in parentheses

\begin{tabular}{|c|c|c|c|}
\hline $\begin{array}{l}\text { Genes upregulated during } \\
\text { growth in human urine } \\
\text { compared to LB }\end{array}$ & Protein & $\begin{array}{l}\text { Number of } \\
\text { genes in operon }\end{array}$ & rLogFC \\
\hline$y b d L$ & Aminotransferase & 1 & 2.453653 \\
\hline$y b d H$ & Hypothetical protein (oxidoreductase) & 1 & 2.351791 \\
\hline metE & $\begin{array}{l}\text { 5-methyltetrahydropteroyltriglutamate-homocysteine } \\
\text { S-methyltransferase }\end{array}$ & 1 & 2.285647 \\
\hline metR & $\begin{array}{l}\text { DNA-binding transcriptional dual regulator for } \\
\text { metE and MetH }\end{array}$ & 1 & 2.236911 \\
\hline yjaB & Hypothetical protein (acetyltransferase) & 1 & 2.137446 \\
\hline metA & Homoserine O-succinyltransferase & 1 & 2.033752 \\
\hline $\begin{array}{l}\arg C ; \\
\arg B\end{array}$ & $\begin{array}{l}\text { N-acetyl-gamma-glutamyl-phosphate reductase; } \\
\text { Acetylglutamate kinase }\end{array}$ & 2 & 2.026239 \\
\hline metF & 5,10-methylenetetrahydrofolate reductase & 1 & 2.010415 \\
\hline $\arg E$ & Acetylornithine deacetylase & 1 & 1.957286 \\
\hline$i l v Y$ & IIVY DNA-binding transcriptional dual regulator & 1 & 1.947862 \\
\hline $\arg D$ & $\begin{array}{l}\text { bifunctional N-succinyldiaminopimelate-aminotransferase } \\
\text { /acetylornithine transaminase }\end{array}$ & 1 & 1.91199 \\
\hline yibl & Hypothetical protein & 1 & 1.905502 \\
\hline artJ & Arginine-binding periplasmic protein 2 & 1 & 1.808872 \\
\hline $\arg G$ & Argininosuccinate synthase & 1 & 1.797071 \\
\hline $\begin{array}{l}\text { ilvG; } \\
\text { ilvM }\end{array}$ & $\begin{array}{l}\text { Acetolacetate synthase } 2 \text { catalytic subunit; acetolactate } \\
\text { synthase } 2 \text { regulatory subunit }\end{array}$ & 2 & 1.752627 \\
\hline $\begin{array}{l}\text { yifB; } \\
\text { UTI89_C4323 }\end{array}$ & $\begin{array}{l}\text { predicted ATP-dependent protease; } \\
\text { hypothetical protein }\end{array}$ & 2 & 1.711417 \\
\hline$y d c X$ & Hypothetical protein (membrane protein) & 1 & 1.634447 \\
\hline $\begin{array}{l}\text { UT189_C2996; } \\
\text { UTI89_C2997; } \\
\text { UTI89_C2998; } \\
\text { yfdN1; } \\
\text { UTI89_C3000 }\end{array}$ & $\begin{array}{l}\text { bacteriophage } V \text { crossover junction endodeoxyribonuclease; } \\
\text { hypothetical protein; } \\
\text { bacteriophage } V \text { DNA adenine methylase; } \\
\text { hypothetical protein; } \\
\text { hypothetical protein }\end{array}$ & 5 & 1.618326 \\
\hline $\mathrm{Crl}$ & DNA-binding transcriptional regulator $\mathrm{Crl}$ & 1 & 1.554786 \\
\hline potF & putrescine $A B C$ transporter substrate-binding protein & 1 & 1.529378 \\
\hline metJ & transcriptional repressor protein MetJ & 1 & 1.513308 \\
\hline yibH & Hypothetical protein (membrane protein) & 1 & 1.511398 \\
\hline UTI89_C2260 & Hypothetical protein & 1 & 1.503588 \\
\hline $\begin{array}{l}\text { UT189_C0254; } \\
\text { UT189_C0255; } \\
\text { UT189_C0256 }\end{array}$ & $\begin{array}{l}\text { Hypothetical protein; } \\
\text { Hypothetical protein (peptidase C39); } \\
\text { Hypothetical protein }\end{array}$ & 3 & 1.502547 \\
\hline
\end{tabular}


Table 4 BLAST results of hypothetical proteins are represented in parentheses

\begin{tabular}{|c|c|c|c|}
\hline $\begin{array}{l}\text { Genes downregulated during } \\
\text { growth in human urine compared to LB }\end{array}$ & Protein & $\begin{array}{l}\text { Number of } \\
\text { genes in operon }\end{array}$ & rLogFC \\
\hline $\begin{array}{l}\text { fliF; } \\
\text { fliG; } \\
\text { fliH; } \\
\text { fliil }\end{array}$ & $\begin{array}{l}\text { flagellar MS-ring protein; } \\
\text { flagellar motor switch protein G; } \\
\text { flagellar assembly protein } \mathrm{H}_{;} \\
\text {flagellum-specific ATP synthase }\end{array}$ & 4 & 2.177048 \\
\hline fliE & flagellar hook-basal body protein FliE & 1 & 2.158562 \\
\hline UTI89_C3136 & $\begin{array}{l}\text { Hypothetical protein } \\
\text { (FAD-linked oxidoreductase) }\end{array}$ & 1 & 1.979745 \\
\hline ybek & Hypothetical protein (hydrolase) & 1 & 1.857649 \\
\hline $\operatorname{nadC}$ & quinolinate phosphoribosyltransferase & 1 & 1.789156 \\
\hline nagA & N-acetylglucosamine-6-phosphate deacetylase & 1 & 1.739815 \\
\hline $\begin{array}{l}\text { menE; } \\
\text { menC; } \\
\text { menB }\end{array}$ & $\begin{array}{l}\text { O-succinylbenzoic acid-CoA ligase; } \\
\text { O-succinylbenzoate synthase; } \\
\text { naphthoate synthase }\end{array}$ & 3 & 1.731787 \\
\hline gals & DNA-binding transcriptional regulator GalS & 1 & 1.715122 \\
\hline UTI89_C0374 & $\begin{array}{l}\text { Hypothetical protein } \\
\text { (nucleoprotein/polynucleotide-associated enzyme) }\end{array}$ & 1 & 1.701595 \\
\hline$f a d B$ & multifunctional fatty acid oxidation complex subunit alpha & 1 & 1.682517 \\
\hline $\begin{array}{l}\text { ampD; } \\
\text { ampE }\end{array}$ & $\begin{array}{l}\mathrm{N} \text {-acetyl-anhydromuranmyl-L-alanine amidase; } \\
\text { regulatory protein AmpE }\end{array}$ & 2 & 1.671218 \\
\hline $\begin{array}{l}\text { narG; } \\
\text { narH; } \\
\text { narJ; } \\
\text { narl }\end{array}$ & $\begin{array}{l}\text { respiratory nitrate reductase } 1 \text { subunit alpha; respiratory } \\
\text { nitrate reductase } 1 \text { subunit beta; } \\
\text { nitrate reductase } 1 \text { subunit delta; } \\
\text { nitrate reductase } 1 \text {, cytochrome b(NR) subunit gamma }\end{array}$ & 4 & 1.630201 \\
\hline lacl & lac repressor & 1 & 1.604708 \\
\hline $\begin{array}{l}\text { pepQ; } \\
\text { yigZ }\end{array}$ & $\begin{array}{l}\text { Proline depeptidase; } \\
\text { hypothetical protein }\end{array}$ & 2 & 1.580097 \\
\hline yiim & $\begin{array}{l}\text { Hypothetical protein } \\
\text { (6-N-hydroxylaminopurine resistance protein) }\end{array}$ & 1 & 1.559754 \\
\hline ујем & Transporter YjeM & 1 & 1.536508 \\
\hline purC & $\begin{array}{l}\text { phosphoribosylaminoimidazole-succinocarboxamide } \\
\text { synthase }\end{array}$ & 1 & 1.528491 \\
\hline ynfK & dithiobiotin synthetase & 1 & 1.508037 \\
\hline ybas & Glutaminase & 1 & 1.507194 \\
\hline hlyA & hemolysin A & 1 & 1.50293 \\
\hline ybar & copper-transporting P-type ATPase & 1 & 1.501551 \\
\hline
\end{tabular}

the 23 genes identified with DFI-seq to be upregulated in human urine (marked in bold in Table 3), 16 were confirmed. Of the 19 genes downregulated in human urine (marked in bold in Table 4), eight were confirmed. Three genes (ybaS, nagA and narG) yielded inconsistent results as they were identified as upregulated in DFI-seq but downregulated by RT-qPCR. An explanation for this could be that regulatory elements of these promoters may have been omitted during the DFI library construction.

Twelve of the 15 genes identified by DFI were also identified in DFI-seq. In Fig. 4, a Venn diagram showing the extensive overlap of the DFI and DFI-seq results, is presented. DFI-seq yields a larger set of unique gene identifications compared to DFI. It further allows for identification of upregulated as well as downregulated promoters in the same experiment, thus providing a more comprehensive overview of changes in the transcriptional activity during bacterial growth in human urine vs. LB.

\section{Functional assessment of urine-induced UPEC genes}

A total of 18 genes from both screens were selected for functional investigation. The 18 genes were deleted using the Lambda-Red-mediated recombination method devised by Datsenko and Wanner [27]. Two thirds of the selected 

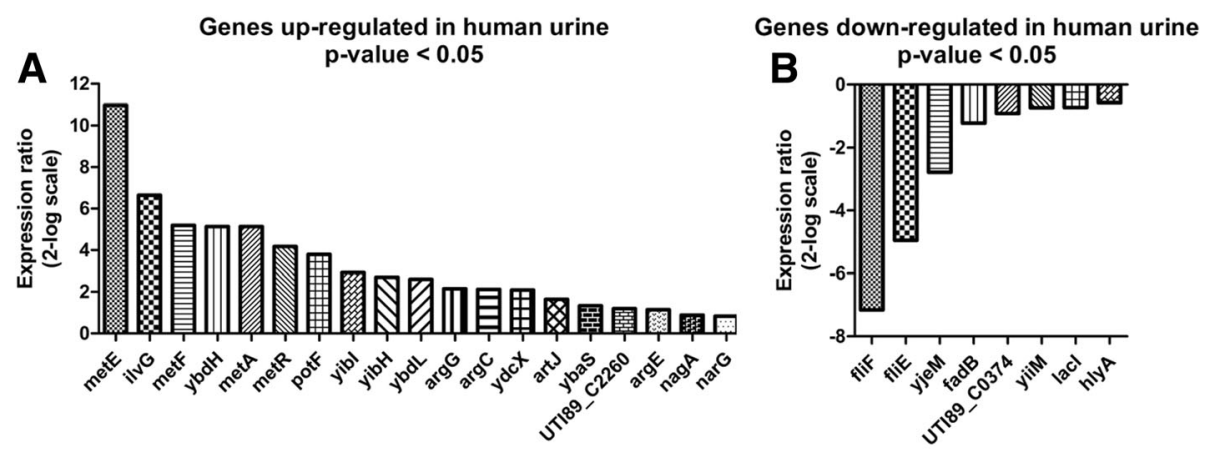

Genes neither up- nor down-regulated in human urine

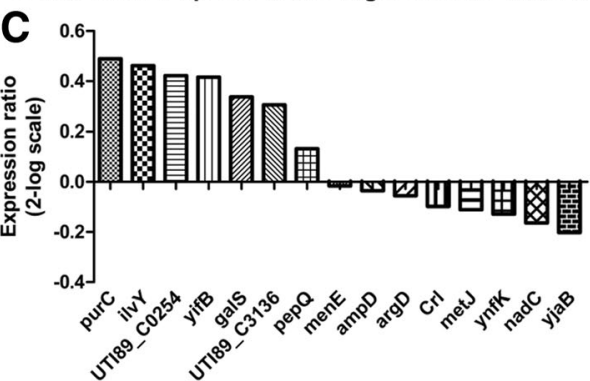

Fig. 3 RT-qPCR verification of differentially expressed genes identified in the DFl-seq experiment. RT-qPCR was performed on bacterial RNA isolated from UTI89 grown in human urine and LB, respectively. $\mathbf{a}$ and $\mathbf{b}$ Expression ratios (log2 scale) of genes differentially expressed in human urine compared to LB, with $P<0.05$. c Gene expression ratios (log2 scale) of uniformly expressed genes $(P>0.05)$. A pairwise fixed reallocation randomisation test was performed [45] and exact $p$-values can be found in Additional file 11: Table S2

genes are known to be directly or indirectly involved in amino acid metabolism, exceptions being potF, $y b d H$, $y b d L$, yeaR, $y i b I$ and $y j a B$. The potF and $y b d L$ genes encode putrescine $A B C$ transporter substrate-binding protein and an aminotransferase respectively; the remaining four genes all encode hypothetical proteins. By BLAST

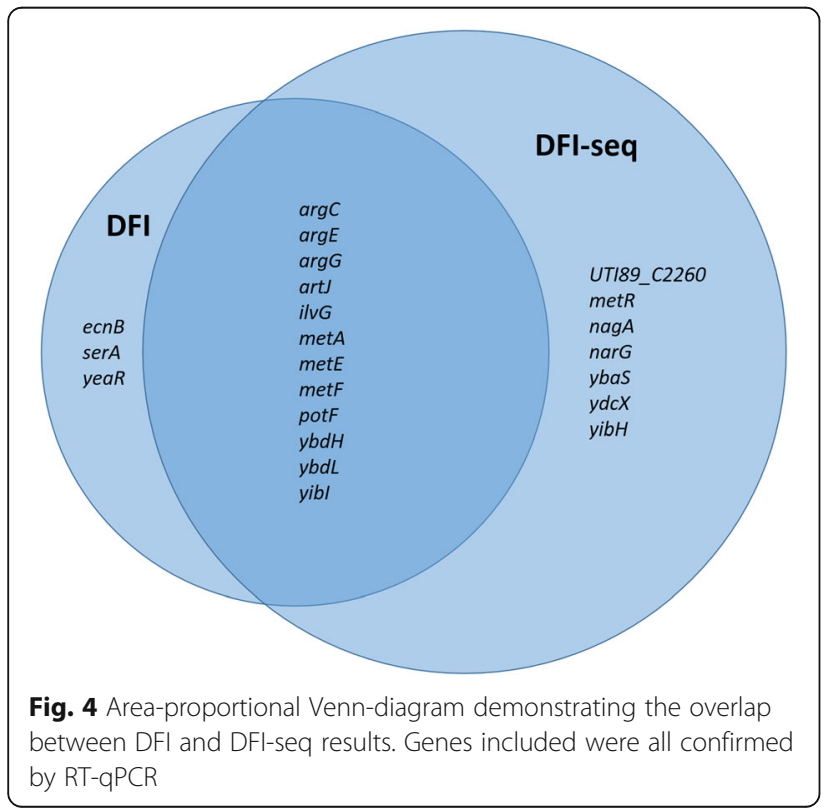

analysis these were predicted to encode an oxidoreductase $(y b d H)$, proteins of unknown function (yeaR and $y i b I$ ), and an acetyl transferase $(y j a B)$.

To assess the effect of deletion mutations on UTI89 fitness in human urine, competition assays were employed. The 18 mutant strains were grown in human urine in a 1:1 ratio with the UTI89 wild type. After $24 \mathrm{~h}$, 15 of the mutants were significantly outcompeted to varying degrees (Fig. 5a).

All mutants affected in L-arginine biosynthesis were outcompeted during growth in human urine. The $\operatorname{argA}$, $\arg B, \arg C, \arg E$ and $\arg G$ mutants had competitive indexes (CIs) of only 0.12, 0.02, 0.11, 0.14 and 0.000007, respectively. For genes involved in methionine biosynthesis the CIs were 0.19 (metA), 0.06 (metE), 0.03 (metF) and 0.15 (metR). Other genes directly or indirectly involved in amino acid metabolism were important for fitness, displaying CIs of 0.11 (artJ and serA) and 0.15 $(i l v G)$. Mutants in $y e a R$ or $y j a B$, two genes with unknown function, the CIs were 0.37 for both, and for the $y i b I$ mutant it was 0.33 . Disruption of potF, $y b d H$ and $y b d L$ did not result in a statistically significant fitness defect (Additional file 1: Figure S1).

Urine is the environment encountered by UPEC before invasion of BECs and it is therefore reasonable to investigate whether the 18 genes might have an influence on the invasion or intracellular proliferation of UTI89 in 

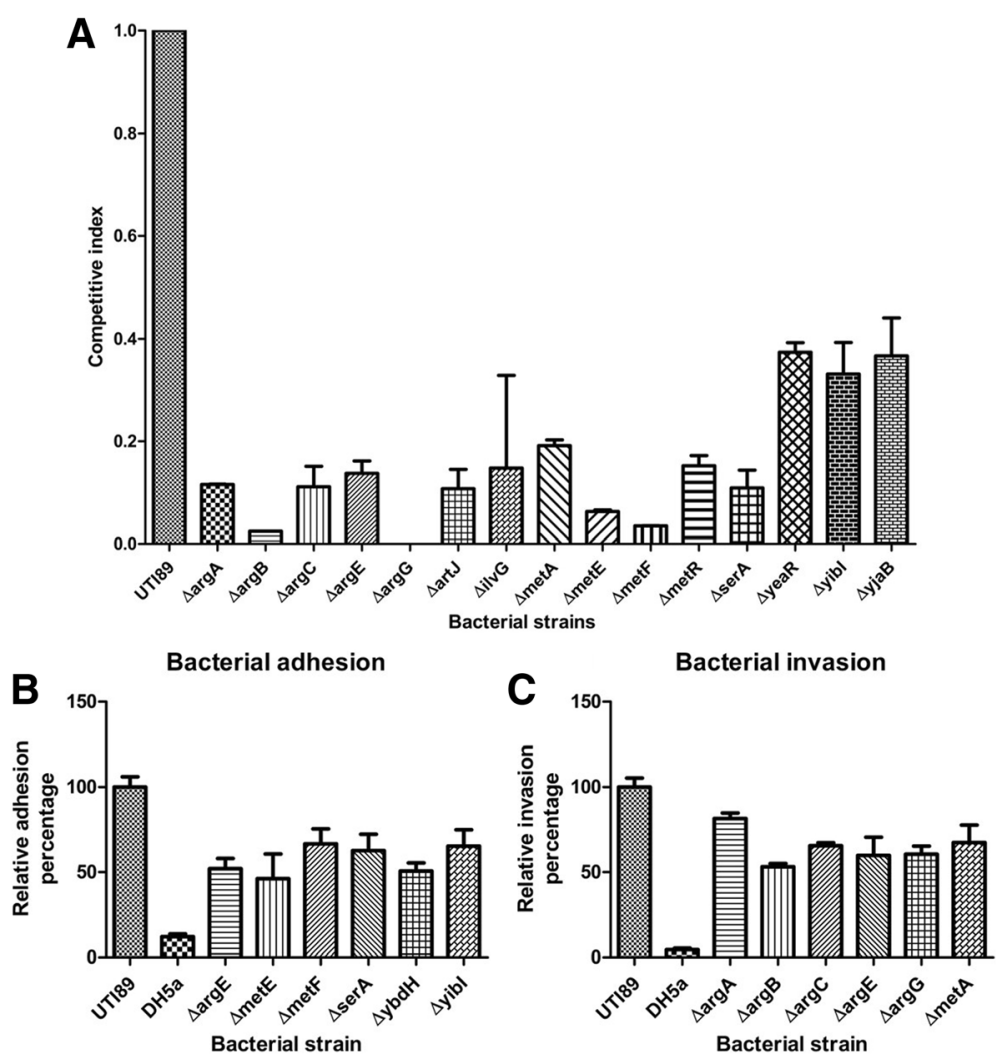

Fig. 5 Fitness and relative cell adhesion and invasion of select deletion mutants. a Competitive index of deletion mutants during growth in human urine. The standard error of the mean of two independent 24-h growth experiments is shown $(P<0.05)$, the exact $p$-value can be seen in Additional file 7: Additional file 7: Table S3. b Mutants with statistically significant $(P<0,05)$ adhesion defects to J82 cells, the exact $p$-value can be seen in Additional file 9: Table S4. c Mutants with statistically significant $(P<0,05)$ invasion defects the exact $p$-value can be seen in Additional file 8: Table 55. The standard error of the mean of three independent assays is shown. $\mathbf{a}, \mathbf{b}$ and $\mathbf{c}$ Unpaired t tests with two-tailed p-values were performed using GraphPad Prism 5 software

BECs. The BEC-line J82 was infected with wild type UTI89 or mutant strains at a multiplicity of infection (MOI) of 100. After gentamicin-protection assays intracellular survival was evaluated. All null mutants affected in L-arginine biosynthesis showed an attenuated ability to invade BECs along with UTI89 $\Delta$ metA (Fig. 5c). The remaining mutants showed no statistically significant difference in their ability to invade the J82 BECs (Additional file 2: Figure S2).

We investigated whether the reduction in intracellular bacterial counts of the $m e t A$ and $\arg$ mutants was due to impaired BEC adhesion. Among the null mutants affecting L-arginine biosynthesis, only the $\triangle \operatorname{argE}$ mutant displayed a reduced adhesion capacity. In addition to $\arg E$, the deletion of five other genes resulted in reduced adherence to BECs, metE, metF, $s e r A, y b d H$, and $y i b I$ (Fig. 5b). The remaining mutants showed no statistically significant difference in their ability to adhere to the J82 BECs (Additional file 3: Figure S3).

\section{Identification of BEC-induced UTI89 genes using DFI-seq}

Having validated the use of DFI-seq in human urine we next moved on to employ the method on infected bladder cells. The J82 BEC line was infected with the UTI89 promoter trap library at an MOI of 10 and as control the library was grown simultaneously in DMEM media. The low MOI was used to minimize the incidence of single-cell invasion by multiple non-clonal bacteria. The two samples were subjected to FACS-based isolation of green-fluorescent BECs or bacteria, respectively.

In DMEM medium, $2.6 \%$ of the population was found to be fluorescent and in the $\mathrm{BEC}$ sample this percentage was $0.4 \%$. From the BEC sample 4,320 events were sorted, whereas 193,105 events were sorted from the bacterial sample. 10,736,670 reads from the BEC sample and $14,820,780$ reads from the bacterial sample were mapped to the UTI89 genome. The average read length was $50 \mathrm{bp}$ in both samples, and the fraction uniquely mapping to the UTI89 genome was 60.93 and $69.65 \%$, respectively. 
Table 5 UTI89 genes upregulated in J82 BECs. BLAST results of hypothetical proteins are represented in parentheses

\begin{tabular}{|c|c|c|c|}
\hline Genes upregulated during growth in J82 BECs & Protein & Number of genes in operon & rLogFC \\
\hline $\operatorname{trpR}$ & Trp operon repressor & 1 & 2,332854642 \\
\hline yaaU & metabolite transport protein YaaU & 1 & 2,283687208 \\
\hline UT189_C4979 & hypothetical protein (Transposase) & 1 & 2,249895676 \\
\hline UT189_C4140 & hypothetical protein & 1 & 2,15066842 \\
\hline rluA & $23 \mathrm{~S}$ rRNA/tRNA pseudouridine synthase A & 1 & 2,07065298 \\
\hline $\begin{array}{l}\text { pepQ; } \\
\text { yigZ }\end{array}$ & $\begin{array}{l}\text { Proline dipeptidase; } \\
\text { hypothetical protein }\end{array}$ & 2 & 1,975901548 \\
\hline UT189_C5123; UT189_C5124 & $\begin{array}{l}\text { tail component of prophage CP-933 Ki } \\
\text { tail component of prophage CP-933 K }\end{array}$ & 2 & 1,86063772 \\
\hline$|p| A$ & lipoate-protein ligase A & 1 & 1,852945008 \\
\hline ycel & hypothetical protein & 1 & 1,840726794 \\
\hline UT189_C5140 & hypothetical protein & 1 & 1,83941429 \\
\hline UT189_C5136 & hypothetical protein (putative membrane protein) & 1 & 1,837077447 \\
\hline UT189_C5163 & hypothetical protein (transcriptional regulator) & 1 & 1,72527562 \\
\hline UT189_C5093 & hypothetical protein (Phytoene synthase) & 1 & 1,701749646 \\
\hline yfdQ2 & hypothetical protein (phage protein) & 1 & 1,699919702 \\
\hline deoA & thymidine phosphorylase & 1 & 1,698786977 \\
\hline UT189_C5087; UT189_C5088 & $\begin{array}{l}\text { hypothetical protein (phage protein); } \\
\text { hypothetical protein (HNH endonuclease) }\end{array}$ & 2 & 1,689083782 \\
\hline UTI89_C0227 & LysR family transcriptional regulator & 1 & 1,666994808 \\
\hline yjj & $\begin{array}{l}\text { hypothetical protein } \\
\text { (transcriptional regulator) }\end{array}$ & 1 & 1,659851375 \\
\hline UT189_C5141 & hypothetical protein & 1 & 1,65493764 \\
\hline yjjk & ABC transporter ATP-binding protein & 1 & 1,65080455 \\
\hline $\begin{array}{l}\text { deoB; } \\
\text { deoD }\end{array}$ & $\begin{array}{l}\text { Phosphopentomutase; } \\
\text { purine nucleoside phosphorylase }\end{array}$ & 2 & 1,637364571 \\
\hline UT189_C5086 & $\begin{array}{l}\text { hypothetical protein } \\
\text { (putative membrane protein) }\end{array}$ & 1 & 1,619322431 \\
\hline yecH & hypothetical protein & 1 & 1,607068129 \\
\hline yafD & $\begin{array}{l}\text { hypothetical protein } \\
\text { (EEP domain-containing protein) }\end{array}$ & 1 & 1,587086745 \\
\hline UT189_C5108 & hypothetical protein & 1 & 1,572251909 \\
\hline Slt & lytic murein transglycosylase & 1 & 1,55866374 \\
\hline UT189_C5139 & hypothetical protein & 1 & 1,551006847 \\
\hline UT189_C5078 & hypothetical protein & 1 & 1,539466639 \\
\hline osmY & periplasmic protein & 1 & 1,536342614 \\
\hline UTI89_C5146 & hypothetical protein (membrane protein) & 1 & 1,529533673 \\
\hline $\begin{array}{l}y j j \mathrm{j} ; \\
y j j \mathrm{Z}\end{array}$ & $\begin{array}{l}\text { hypothetical protein (phospholipase); } \\
\text { deoxyribonuclease YjjV } \\
\text { (metal-dependent hydrolase) }\end{array}$ & 2 & 1,525815587 \\
\hline$d n a C$ & DNA replication protein DnaC & 1 & 1,525438036 \\
\hline UT189_C3195 & hypothetical protein & 1 & 1,510078684 \\
\hline yjjM & $\begin{array}{l}\text { hypothetical protein } \\
\text { (GntR family transcriptional regulator) }\end{array}$ & 1 & 1,504013167 \\
\hline
\end{tabular}


Table 6 UTI89 genes downregulated in J82 BECS. BLAST results of hypothetical proteins are represented in parentheses. Genes located on the UTI89 plasmid are marked in bold

\begin{tabular}{|c|c|c|c|}
\hline $\begin{array}{l}\text { Genes downregulated during growth in J82 } \\
\text { BECs }\end{array}$ & Protein & $\begin{array}{l}\text { Number of genes in } \\
\text { operon }\end{array}$ & rLogFC \\
\hline repB & replication protein & 1 & 2,011113132 \\
\hline htgA & positive regulator for sigma 32 heat shock promoters & 1 & 1,890514455 \\
\hline UT189_P010 & $\begin{array}{l}\text { hypothetical protein (iron permease/transporter (membrane } \\
\text { protein)) }\end{array}$ & 1 & 1,861559188 \\
\hline ribF & bifunctional riboflavin kinase/FMN adenylyltransferase & 1 & 1,859516233 \\
\hline yaar & hypothetical protein & 1 & 1,848940285 \\
\hline ydiA & hypothetical protein & 1 & 1,753697215 \\
\hline gyrB & DNA gyrase subunit B & 1 & 1,74780503 \\
\hline rob & right origin-binding protein & 1 & 1,738152589 \\
\hline yajk & thiamine biosynthesis protein Thil & 1 & 1,638543917 \\
\hline creA & $\begin{array}{l}\text { hypothetical protein (protein CreA (Catabolite regulation } \\
\text { protein A)) }\end{array}$ & 1 & 1,635400678 \\
\hline$y t f B$ & hypothetical protein (Opacity-associated protein A) & 1 & 1,617894201 \\
\hline UT189_P053 & hypothetical protein & 1 & 1,614324659 \\
\hline yjjx & NTPase & 1 & 1,60329406 \\
\hline UT189_P144 & hypothetical protein (putative endonuclease) & 1 & 1,577892223 \\
\hline$y c c W$ & $\begin{array}{l}\text { hypothetical protein (ribosomal RNA large subunit } \\
\text { methyltransferase) }\end{array}$ & 1 & 1,516636602 \\
\hline UTI89_P046; UTI89_P047 & $\begin{array}{l}\text { hypothetical serine-threonine protein kinase } \\
\text { hypothetical protein }\end{array}$ & 2 & 1,513872693 \\
\hline
\end{tabular}

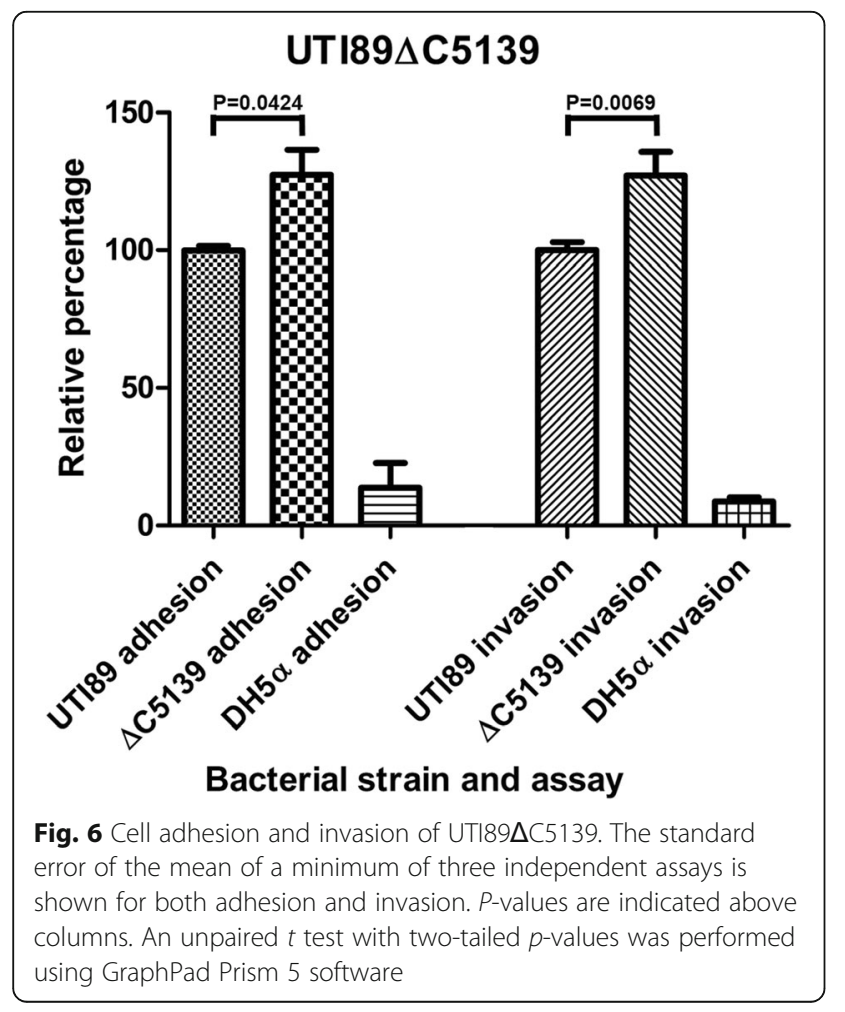

The number of reads mapping to a defined promoter was compared between the two samples, leading to the identification of 34 promoter regions upregulated inside BECs with a positive rLogFC of at least 1.5. 16 promoter regions were identified to be downregulated inside BECs with a negative rLogFC of -1.5 or less. Genes and defined operons with an absolute rLogFC of at least 1.5 are listed in Table 5 (upregulated genes) and Table 6 (downregulated genes).

Among the 16 downregulated regions, six were placed on the UTI89 plasmid (marked in bold in Table 6). One of the plasmid-encoded genes encodes a product with known function; $\operatorname{rep} B$, is involved in controlling plasmid replication. Of the ten downregulated chromosomally encoded genes, four encode hypothetical proteins. 23 out of 39 upregulated genes encode hypothetical proteins, ten of which could not be assigned by BLAST to a protein function or a cellular location.

One gene was chosen for further investigation to show that validity of the method for identification of genes involved in invasion. UTI89_C5139 was deleted from the UTI89 chromosome and tested for cell adhesion and invasion using the BEC-line J82 at an MOI of 100 (Fig. 6). The UTI89_C5139 mutant displayed a significant increase of $25 \%$ in both cellular adhesion and invasion. The amino acid sequence (Uniprot; Q1R275-1) of the protein encoded by UTI89_C5139 was analysed for presence 
of transmembrane helices using the TMHMM program (http://www.cbs.dtu.dk/services/TMHMM/) and was found to contain one transmembrane helix near the $\mathrm{N}$ terminal suggesting the protein could be located in the outer membrane. Of the remaining 22 hypothetical genes found to be upregulated, four encode proteins that were found to contain transmembrane helices (Additional file 4: Table S6). Three of these proteins were by BLAST found to be putative membrane proteins (Table 5). UTI89_C5136, UTI89_C5146 and UTI89_C5068 have four, two and four transmembrane helices respectively. The remaining gene UTI89_C5140 encodes a protein which contains a single transmembrane helix located near the N-terminal. UTI89_C5140 is located 53 bases downstream from UTI89_C5139 on the same strand, suggesting that these two genes might be transcribed simultaneously during infection.

\section{Discussion}

The knowledge about UPEC fitness and virulence gene expression in the urinary tract is far from complete and with the emergence of multidrug-resistant (MDR) UPEC strains, limiting the available treatment options, new strategies are necessary to prevent UTIs [28]. A deeper understanding of UPEC adaption to the urinary tract, its fitness and pathogenicity would help in the search for new treatment or prevention options.

Gene expression is usually investigated by microarray analysis or, in recent years, by RNA-seq. By measuring specific RNA levels, both methods can give a genomewide view of gene expression in a bacterial population. Both methods have been used on urine samples from patients with UTIs $[29,30]$. However, when investigating infected tissue limitations arise. RNA purification of mixed samples results in an overwhelming amount of eukaryotic RNA that will diminish the information content that can be derived from the bacterial RNA by conventional approaches [31].

Another way to study environment-specific gene induction is by screening promoter trap libraries, which circumvents the need for RNA purification. It can be done using a conditionally essential reporter gene as done in in vivo expression technology (IVET) or a fluorescence marker as done in DFI [22]. IVET identifies genes that are constitutively and highly expressed. However, this method fails to detect transiently or weakly expressed genes, a limitation that was overcome with the introduction of the DFI method [32]. DFI and DFI-seq are not biased by the absolute expression levels of the selectable marker, and weakly and highly fluorescent clones are therefore sorted with equal efficiency. The DFI strategy is based on consecutive rounds of FACS based on differential GFP expression. The $g f p$ gene has been replaced by a gfp_ovalbumin ( $f f p$-ova) gene fusion [22], which encodes a destabilized GFPOvalbumin reporter fusion with less impact on bacterial fitness. This also enables examination of the active promoters in an environment at a specific time point, giving a snapshot of the activated genes. Both IVET and DFI only identify upregulated genes and eliminate housekeeping genes from the promoter trap library. In DFI this is achieved during the consecutive sorts. These consecutive sorts are time consuming and can introduce bias, however too few sorts can give to many false positive gene identifications.

In the previous DFI studies conducted by Valdivia et al. [21,32] only three consecutive sorts were used. Here we used five sorting steps in order to reduce the number of false-positives (Table 1). Of the 25 clones picked for the confirmation of urine-specific GFP induction, 76\% had a higher fluorescence in human urine compared to LB (Table 2). The induction of gene promoters measured by GFP-Ovalbumin protein, was confirmed using RTqPCR. However, the increase in mean GFP fluorescence (Table 2) does not accurately reflect the change in mRNA level for a particular promoter (Fig. 2). During insertion of DNA fragments into the promoter trap plasmid, we may inadvertently have altered promoter activity, for example by excluding transcription factor binding sites from the inserted fragment.

By introducing DFI-seq, we attempt to simplify the DFI method and at the same time harness the power of NGS to generate genome-wide rather than clonal data. DFI-seq eliminates the need for consecutive sorting of the bacterial library, and thereby limits the bias that can be introduced. The method however can introduce bias due to overnight growth of the sorted bacteria, as with DFI, and when PCR amplifying the promoters before NGS. However, the method can identify both up- and downregulated genes in a single sorting step. The data from DFI and DFI-seq largely overlap, thus validating the use of the DFI-seq method over traditional DFI. By reducing bias DFI-seq diminishes the chance for generation of false-positive identifications. To increase the stringency of DFI-seq experiments and reduce the chances of generating false positives due to the biases that might be introduced, biological replicates should be included in the DFI-seq experiments. However, the possibility of excluding transcriptional factor binding sites still exist and DFI-seq should therefore be considered mainly as a qualitative discovery tool that requires RTqPCR for quantitation of individual promoter outputs.

Human urine contains few amino acids and these serve as the main carbon source for bacteria growing in the urinary tract [33]. Biosynthesis of amino acids can therefore be considered a fitness factor for UPEC during UTI. Our results support this view, as $55 \%$ of the 22 genes confirmed by RT-qPCR to be upregulated in 
human urine (Figs. 2 and 3) were directly or indirectly involved in amino acid biosynthesis.

Serine and methionine biosynthesis have previously been reported to be necessary for optimal fitness of UPEC in human urine [34] and our observations were in accordance to this. The serA gene encodes D-3phosphoglycerate dehydrogenase. This enzyme uses $\mathrm{NAD}^{+}$in the conversion of 3-phospho-D-glycerate to 3phosphohydroxypyruvate as a first step in serine biosynthesis [35]. In RT-qPCR the serA gene had an expression ratio of 2.3 (Fig. 2a), corresponding to an almost fivefold upregulation during growth in human urine compared to LB. This is in agreement with the findings by Alteri et al., which identified differentially expressed proteins in UPEC strain CFT073 during growth in human urine and iron-limited LB by comparative proteomics [20]. The serA null mutant was inhibited in its ability to adhere to J82 BEC (Fig. 5 b) by about $60 \%$ compared to the wildtype, and displayed a $\mathrm{CI}$ of 0.11 during growth in human urine (Fig. 5a). We did not detect a significant difference between wildtype UTI89 and UTI89 1 serA during invasion of BEC-line J82. Alteri et al. showed that a serA mutant of UPEC strain CFT073 was not significantly out-competed by wild type CFT073 in vivo $48 \mathrm{~h}$ post infection of mice [20] and the mutant suffered only a slight fitness defect. These results taken together suggest that the effect of the serA gene is mainly related to growth in urine prior to host cell invasion.

Genes involved in methionine biosynthesis, metA, metE, metF and metR genes were found to be upregulated in human urine (Fig. 3a), while metC was downregulated (Fig. 2b). The metA, metC and metE genes encode enzymes involved in methionine biosynthesis; metE is positively regulated by the MetR DNA-binding transcriptional dual regulator. The metF gene is indirectly involved in methionine biosynthesis. MetF is involved in the biosynthesis of 5-methyltetrahydrofolate, which acts as a substrate for methylation in the last step of methionine biosynthesis in a reaction catalysed by MetE. Deletion mutants of $m e t A$, metE, metF and metR were all less competitive than the wild type during growth in human urine. The metE and metF mutants displayed reduced adhesion to J82 BECs (Fig. 5a), while the met $A$ mutant was inhibited in its ability to invade or proliferate intracellularly in J82 BECs (Fig. 5b). Thus, our results are consistent with the findings of Hull and Hull [34] in showing that Methionine biosynthesis is important for UPEC fitness in urine and that mutations affecting this process can affect the virulence of UPEC, thereby connecting fitness genes to virulence.

Two additional amino acids, whose biosynthesis is important during growth in human urine, are isoleucine and arginine [36]. We found that the ilvG mutant was less competitive than the wild type $(\mathrm{CI}=0,15)$ and that
ilvG was upregulated during growth in human urine (Expression ratio $(\log 2)$ of 6.65). The ilvG and ilvM genes encode the catalytic and regulatory subunit of acetolactate synthase 2, respectively. This enzyme uses pyruvate as a substrate during isoleucine biosynthesis. We did not detect differential expression of $i l v C$, which encodes another enzyme in isoleucine biosynthesis, was differentially regulated in human urine compared to LB (Fig. 2c). This gene has been reported by Snyder et al. to be upregulated in UPEC strain CFT073 during growth in human urine [36].

We analysed deletion mutants in six genes involved in arginine metabolism. The art gene encodes the Arginine-binding periplasmic protein 2, which is part of the Arginine ABC transport system. This system is composed of five proteins encoded by the artP, artI, artQ, artM and artJ genes, all located in succession on the UTI89 chromosome. The artJ null mutant was outcompeted in human urine by the wild type $(\mathrm{CI}=0,11)$, however it was not significantly compromised in is ability to adhere to and invade or proliferate inside J82 BECs. Consistent with our findings, artJ was previously shown to be upregulated during growth on human urine agar plates [37], and upregulated in human urine [36].

Of the five $\arg$ genes investivated $\arg C, \arg E$ and $\arg G$ was confirmed by RT-qPCR to be upregulated. $\arg G$ was previously found to be up-regulated in human urine compared to iron-limited LB [20], and a DNA microarray study on UPEC strain CFT073 found $\operatorname{argB}, \operatorname{argC}$ and $\arg E$ to be upregulated in human urine [36]. All mutants affected in L-arginine biosynthesis were outcompeted during growth in human urine (Fig. 5a), consistent with previous findings [34]. In urine, arginine is present at a suboptimal level for bacterial growth [34]. This could be the reason behind this requirement for endogenous synthesis of arginine in this extracellular environment. Arginine biosynthesis mutants were all inhibited in their ability to invade or proliferate inside $\mathrm{J} 82$ BECs (Fig. 5c) but only the $\operatorname{argE}$ mutant displayed reduced adhesion ability (Fig. 5b). CFT073 $\triangle$ arG has been shown to resist out-competiton by CFT073 wild type in vivo $48 \mathrm{~h}$ post infection of mice [20]. The results however indicated a slight fitness defect in the kidneys but not the bladder. Another study showed that an $\operatorname{argC}$ mutant had a significantly decreased ability to infect the mouse kidney [38]. Taken together these results demonstrate a significant link between amino acid biosynthesis and virulence, and hence support the recent bacterial virulence paradigm suggested by Mobley [19]. Using growth competition assays, we show that the $\arg$ genes contribute to the fitness of UPEC in urine. However, these genes also play a role in the intracellular UPEC proliferation without affecting their initial adhesion to host cells. Thus, the arg genes are not only fitness 
factors but also virulence determinants enabling IBC formation - a charateristic of UPEC pathogenesis. The capacity for biosynthesis of specific amino acids may become critical during intracellular bacterial growth. In support hereof, the amino acid requirements of Salmonella enterica for intracellular proliferation have been shown recently to vary according to the infected cell type [39].

Yet another gene found in our study links back to arginine and methionine, potF. The potF gene encodes a substrate-binding protein, which is part of the $A B C$ transporter of the polyamine putrescine. The predominant polyamines in bacteria are putrescine and spermidine. Arginine can be converted into putrescine and further into Spermidine [39]. Polyamines were found to be important for virulence in Salmonella as a polyamine mutant of Salmonella Typhimurium had a reduced intracellular survival/replication compared to the wild type and was attenuated in the mouse model of typhoid fever [39]. Thus, polyamines may serve as environmental cues for the bacteria to initiate virulence gene expression [39]. UPEC potF has been shown by microarray analyses to be downregulated in response to increased environmental osmolality caused by high salt and urea [40] and when isolated from the urine of infected women [30]. Our data showed that potF was upregulated in human urine compared to LB, but deletion had no effect on cell invasion. The $\mathrm{ABC}$ transporter affected in the pot $F$ deletion mutant is not the only $\mathrm{ABC}$ transporter capable of transporting putrescine, possibly explaining why we do not observe an effect on UPEC virulence in the potF mutant.

To demonstrate the usefulness of DFI-seq in a more complicated experimental setup, BECs were infected with UPEC strain UTI89 and subjected to DFI-seq. Of the 56 genes found to be differentially expressed in the BECs, almost $60 \%$ encoded hypothetical proteins. These may possibly represent virulence factors not yet discovered. To validate the DFI-seq method one gene was chosen for further investigation. The UTI89_C5139 gene encodes a putative membrane protein, which contains a transmembrane domain. The deletion mutant exhibited increased adherence to J82 BECs and increased invasion or intracellular proliferation. UTI89_C5139 was found during DFI-seq to be upregulated during invasion, and a deletion mutant of this gene was expected to be less invasive in ex vivo experiments. The opposite was observed, indicating that the gene product directly or indirectly influences the expression of other virulence genes, possibly limiting their effect to avoid immune system detection or a to high infection rate that might lead to premature exfoliation of the bladder lining both resulting in a lowering of the bacterial burden.

\section{Conclusion}

DFI-seq allowed the positive selection of genes involved in UPEC growth in vitro in human urine as well as during infection of bladder tissue culture. DFI-seq provides a more comprehensive overview of differential gene expression than conventional DFI, it is less timeconsuming and labor-intensive and has fewer handling steps that may introduce bias. We identified genes involved in amino acid metabolism necessary for growth in human urine compared to growth in LB by using DFI-seq. The arginine biosynthesis genes were found to be required for successful infection of BECs, thus strengthening the assertion that fitness and virulence gene expression are both important in UPEC pathogenicity. DFI-seq provides a new avenue for virulence and fitness gene identification using positive selection and we show that it can be used not only with liquid culture but also in cell culture assays. In order to firmly establish a definite role in virulence of the genes identified in this study, animal infection experiments are required. Thus, DFI-seq should be applicable to in vivo infection systems, thus providing important insights into hostinduced changes in gene expression of infecting bacterial pathogens.

\section{Methods}

\section{Bacterial strains, cells, and growth conditions}

The UPEC strain UTI89, a cystitis-derived isolate [5] was used for library construction. UTI89-derived deletion mutants (Table 7) were constructed using the lambda Red recombination [27]. Primers used for mutant construction can be found in Additional file 5: Table S7. Additionally, E.coli DH5 $\alpha$ was used as a nonpathogenic control strain.

Bacterial cultures were grown at $37{ }^{\circ} \mathrm{C}$ in LB medium, DMEM + 10\% FBS, or human urine (USG 1.021) containing $30 \mu \mathrm{g} / \mathrm{mL}$ chloramphenicol $(\mathrm{cml}), 50 \mu \mathrm{g} / \mathrm{mL}$ kanamycin (kan) or $100 \mu \mathrm{g} / \mathrm{mL}$ ampicillin (amp) for plasmid selection. Human urine was prepared for experiments as described previously by Andersen et al. [41].

J82 BECs (ATCC ${ }^{\ominus}$ HTB- $^{\mathrm{mm}}$ ) were maintained at $5 \%$ $\mathrm{CO}_{2}$, as a monolayer in DMEM (ThermoFisher Scientific) containing $10 \%(\mathrm{v} / \mathrm{v})$ heat-inactivated fetal bovine serum (FBS) (Gibco) and Penicillin (100 units/ml)Streptomycin $(100 \mu \mathrm{g} / \mathrm{ml})$ (Gibco).

\section{Library construction}

The UTI89 promoter trap library was constructed as described by Bumann and Valdivia [22] with minor modifications. Chromosomal DNA was purified from an overnight culture of UTI89. Bacterial cells were harvested and resuspended in TE buffer $(0.089 \%$ Trizma hydrochloride (w/v), 0.053\% Trizma base (w/v) and $0.1 \mathrm{mM}$ EDTA), rapid lysis buffer (5\% sodium dodecyl 
Table 7 Bacterial strains and plasmids used in this study

\begin{tabular}{|c|c|c|}
\hline Strain & Genotype & Source \\
\hline UTI89 & Serotype 018:K1:H7 & $\begin{array}{l}\text { [5] Provided by } \\
\text { Emile Van Schaftingen }\end{array}$ \\
\hline $\begin{array}{l}\text { UTI89/ } \\
\text { pMW82 }\end{array}$ & $A m p^{R}$ & This study \\
\hline $\begin{array}{l}\text { UTI89/ } \\
\text { pMWLib }\end{array}$ & $A m p^{R}$ & This study \\
\hline $\mathrm{DH} 5 \mathrm{a}$ & $\begin{array}{l}\text { F- } \text { Ф80lacZ } \Delta \text { M15 } \Delta \text { (lacZYA-argF) } \\
\text { U169 recA1 endA1 hsdR17 } \\
\text { (rK-, mK+) phoA supE44 } \lambda \text { - thi-1 } \\
\text { gyrA96 relA1 }\end{array}$ & Invitrogen \\
\hline UT189 $\Delta \arg C$ & $\Delta \arg C, \mathrm{Cml}^{\mathrm{R}}$ & This study \\
\hline UTI89 $\Delta \arg E$ & $\Delta \arg E, C m l^{R}$ & This study \\
\hline UTI89 $\Delta \arg G$ & $\Delta \arg G, \mathrm{Cml}^{\mathrm{R}}$ & This study \\
\hline UTI89 $\triangle$ artJ & $\Delta$ artJ, $\mathrm{Cml}^{\mathrm{R}}$ & This study \\
\hline UTI89 $\Delta / V G$ & $\Delta i / v G, \mathrm{Cml}^{\mathrm{R}}$ & This study \\
\hline UTI89 $\Delta$ metA & $\Delta m e t A, \mathrm{Cml}^{\mathrm{R}}$ & This study \\
\hline UTI89 $\Delta$ metE & $\Delta m e t E, C_{m l}^{R}$ & This study \\
\hline UT189 $\Delta$ metF & $\Delta m e t F, C l^{R}$ & This study \\
\hline UTI89 $\Delta$ potF & $\Delta p o t F, C m l^{R}$ & This study \\
\hline UTI89 $\Delta y b d H$ & $\Delta y b d H, \mathrm{Cml}^{R}$ & This study \\
\hline UT189 $\Delta y b d L$ & $\Delta y b d L, C m l^{R}$ & This study \\
\hline UTI89 $\Delta$ yibl & $\Delta y i b l, \mathrm{Cml}^{\mathrm{R}}$ & This study \\
\hline UT189 $\Delta \arg A$ & $\Delta \arg A, \mathrm{Cml}^{\mathrm{R}}$ & This study \\
\hline UTI89 $\Delta$ serA & $\Delta \operatorname{ser} A, \mathrm{Cml}^{\mathrm{R}}$ & This study \\
\hline UT189 $\Delta y e a R$ & syear, $\mathrm{Cml}^{\mathrm{R}}$ & This study \\
\hline UTI89 $\Delta \arg B$ & $\triangle \arg B, C m l^{R}$ & This study \\
\hline UTI89 $\Delta$ metR & $\Delta m e t R, \mathrm{Cml}^{\mathrm{R}}$ & This study \\
\hline UTI89 $\triangle y j a B$ & $\Delta y j a B, \mathrm{Cml}^{\mathrm{R}}$ & This study \\
\hline UTI89 & $\Delta C 5139, \operatorname{Kan}^{R}$ & This study \\
\hline Plasmid & Genotype & Source \\
\hline pKD3 & $\mathrm{Cml}$ template plasmid & [28] \\
\hline pKD4 & Kan template plasmid & {$[28]$} \\
\hline pKD46 & $\begin{array}{l}\text { Bla, } \lambda \text { Red recombinase } \\
\text { expression plasmid }\end{array}$ & [28] \\
\hline pMW82 & & $\begin{array}{l}\text { [22] Kindly provided } \\
\text { by Dirk Bumann }\end{array}$ \\
\hline pMWLib & $\begin{array}{l}\text { pMW82 containing random } \\
500-700 \text { bp long UTI89 } \\
\text { DNA segments }\end{array}$ & \\
\hline
\end{tabular}

sulfate (SDS), 0.125 M EDTA, 0.5 M Tris- $\mathrm{HCl} \mathrm{pH}$ 9.4), Ribonuclease A (Sigma Aldrich) and protease (Roche) $\left(37{ }^{\circ} \mathrm{C}\right.$ ) and incubated for $1 \mathrm{~h}$ at $37{ }^{\circ} \mathrm{C}$. Chromosomal DNA was purified by phenol-chloroform extraction, precipitated by addition of 2 vol. $96 \%$ ethanol, and resuspended in TE-buffer.

Purified genomic DNA (100 ng/ml) was disrupted by sonication for $2 \times 30 \mathrm{~s}$ using a Branson Sonifier 250 (Branson Ultrasonics). Resulting fragments of 500$700 \mathrm{bp}$ were purified from a $2 \%$ agarose gel using a GFX PCR DNA and Gel Band purification kit (GE Healtcare) and treated with T4 polymerase (New England Biolabs) for $15 \mathrm{~min}$ at $12{ }^{\circ} \mathrm{C}$ to repair single-stranded regions. The library vector pMW82 was cleaved with BamHI (Fermentas) and SphI (Fermentas), and treated with T4 polymerase to fill in single-stranded overhangs. Next, treatment with shrimp alkaline phosphatase (USB Corporation) was included to prevent vector re-ligation. Finally, genomic fragments and vector DNA was ligated using T4 DNA ligase.

Ligated DNA was introduced into MegaX DH10B ${ }^{\mathrm{TM}}$ $\mathrm{T}^{\mathrm{R}}$ Electrocomp ${ }^{\mathrm{TM}}$ Cells (Invitrogen) by electroporation, and transformants were selected by plating on LB agar containing $100 \mu \mathrm{g} / \mathrm{ml} \mathrm{amp}$. The frequency of vector re-ligation was estimated to be less than $20 \%$. Plasmids were subsequently purified using NucleoBond AX kit (Macherey-Nagel) and transformed into E. coli UTI89 by electroporation. The resulting amp-resistant colonies, together constituting the promoter trap library UTI89/ pMWLib, were pooled and frozen at $-80^{\circ} \mathrm{C}$.

\section{Sorting and FACS analysis of bacterial cells}

Bacterial cells were grown to mid-exponential phase (45 generations) at $37{ }^{\circ} \mathrm{C}$ with aeration in preheated $\mathrm{LB}$ or human urine (USG 1.021) with $100 \mu \mathrm{g} / \mathrm{ml}$ ampicillin or for $1 \mathrm{~h}$ without aeration in preheated DMEM with $10 \%$ FBS. For DFI analysis of UTI89/pMWLib, bacteria grown in urine were sorted based on green fluorescence and bacteria grown in LB were sorted based on the absence of green fluorescence. In DFI-seq, fluorescent bacteria were sorted for all growth conditions, LB, human urine and DMEM. The bacteria were then collected by centrifugation at $3500 \mathrm{xg}$ for $10 \mathrm{~min}$, resuspended in LB and grown overnight.

\section{Sorting and FACS analysis of BECs}

J82 grown to confluence in $15 \mathrm{~cm}$ dishes or 6-well plates were infected at an MOI of 10 for $1 \mathrm{~h}$ at $37^{\circ} \mathrm{C}$. The cells were then washed three times with PBS to remove noninvading bacteria and incubated in DMEM with $10 \%$ FBS and $100 \mu \mathrm{g} / \mathrm{ml}$ gentamicin for $2 \mathrm{~h}$. Next, infected cells were washed three times with PBS to remove the gentamicin before $0.25 \%$ trypsin-EDTA was added for $5 \mathrm{~min}$ to release the cells into suspension. The cells were 
collected by centrifugation at $150 \times \mathrm{g}$ and $4{ }^{\circ} \mathrm{C}$ for 10 min and resuspended in PBS containing 10\% FBS.

J82 cells emitting green fluorescence were collected by cell sorting, using a FACSAria II. In order to preserve the samples, cell sorting was performed for a maximum of $1 \mathrm{~h}$ per sample, so several infection assays were set up to allow for successive sorting of multiple samples. Finally, bacteria were released from the J82 cells by addition of $1 \%$ Triton X-100 and vortexing for $60 \mathrm{~s}$. The bacteria were then collected by centrifugation at $3500 \times \mathrm{g}$ for $10 \mathrm{~min}$, resuspended in LB and grown overnight.

\section{Sequencing and analysis of sequence data after DFI}

Following FACS-based enrichment, the bacterial cells were plated on LB agar with $100 \mu \mathrm{g} / \mathrm{ml}$ amp and grown overnight at $37{ }^{\circ} \mathrm{C}$. Resistance Fragment Length Polymorphisms (RFLP) patterns [22] were analysed by agarose gel separation. 95 colonies were sequenced using primers P1 (5'-TGAAGGCTCTCAAGGGCATC-3') and P2 (5'-GTGTTGGCCATGGAACAGGT-3'). Sequences were aligned, using BLAST, with the $E$. coli UTI89 chromosome and pUTI89 sequences (NCBI database accession number NC007946 and NC007941). Annotation of fragments was performed using Ecocyc.org [42].

\section{Quantitative real time RT-PCR}

Primers for RT-qPCR listed in Additional file 6: Table S8 were designed using Primer3 software [43, 44]. Total RNA was isolated by phenol/chloroform extraction from UTI89/pMW82 grown to mid-exponential phase (4-5 generations) at $37{ }^{\circ} \mathrm{C}$ with aeration in $\mathrm{LB}$ and human urine (USG 1.021), respectively. $1 \mu \mathrm{g}$ of total RNA was treated with DNase I for $30 \mathrm{~min}$ at $37{ }^{\circ} \mathrm{C}$, followed by heat inactivation of the enzyme. Purified RNA was then used for cDNA synthesis using the Maxima first strand cDNA synthesis kit (Thermo Scientific). Real time quantification was performed using $\mathrm{SYBR}^{\circ}$ Select Master Mix (Life Technologies) as specified by the manufacturer. RT-qPCR reactions were run in 96-well plates in an Mx3005P QPCR System (Agilent Technologies) using rrs $A$ and $r p o B$ mRNA as internal controls. Measurements were performed in at least three technical replicates to enable determination of the relative fold change in mRNA expression between UTI89 grown in urine and LB [45].

\section{Sequencing and analysis of sequence data after DFI-seq} Plasmids were purified from sorted UTI89/pMWLib using NucleoBond PC 500 kit (Macherey-Nagel) as specified by the manufacturer. PCR amplification of the inserted chromosome segments in pMWLib was performed using primers P1 (5'-TGAAGGCTCTCAAGGGCATC-3') and P2 (5'-GTGTTGGCCATGGAACAGGT-3'). For Illumina sequencing, the DNA fragments were sonicated into 250-
400 bp long segments from the original size of 500 $700 \mathrm{bp}$, and sequencing library preparation was performed according to the manufacturer's instructions (Illumina) as described previously [25]. The library was sequenced using the Illumina HiSeq 1500 instrument.

Reads were aligned using STAR version 2.3.1z_r395 with spliced mapping disabled. Subsequently, uniquely aligning reads overlapping operon promoters were counted, and DESeq2 was used to identify promoters that were utilized differentially in the urine sample. The rLogFC was calculated. A positive rLogFC means that more reads map to a particular operon promoter region in the sample grown in human urine compared to LB. The opposite is true of a negative score. Operon promoters were defined as the region spanning from $300 \mathrm{bp}$ upstream of the transcription start site to $50 \mathrm{bp}$ downstream. Operons were defined as bookended transcripts, i.e. genes with no base pairs separating them.

\section{Competitive index}

The fitness of single-gene deletion mutants was compared to that of the wild type in a growth competition assay. Cultures grown overnight with aeration in LB, washed in PBS and mixed in a 1:1 ratio (wild type:mutant) in human urine (USG 1.021). Bacteria were plated on LB agar withand without chloramphenicol at the beginning of the experiment and after $24 \mathrm{~h}$ in order to determine the ratio of wild type versus mutant. The competitive index is defined as the output ratio of CFU of mutant to wild type bacteria divided by the input ratio of CFU of mutant to wild type bacteria. Thus, if a mutant strain is as competitive as its isogenic wild type parent, a value of 1 will be achieved, indicating that the mutant is not attenuated.

\section{Adhesion and infection assay}

J82 were seeded into 24-well plates and grown to confluence at which point they were infected at an MOI of 100. The cells were washed three times in PBS to remove the antibiotic-containing DMEM and incubated for $1 \mathrm{~h}$ in prewarmed DMEM before addition of bacteria. The plates were centrifuged at $500 \mathrm{xg}$ for $5 \mathrm{~min}$ to synchronize infection, and incubated for $1 \mathrm{~h}$ at $37{ }^{\circ} \mathrm{C}$. The cells were then washed three times with PBS to remove non-adherent bacteria. To measure bacterial adherence, J82 cells were lysed by addition of $100 \mu \mathrm{l} 0.25 \%$ trypsin-EDTA and $400 \mu \mathrm{L} 0.1 \%$ Triton X-100 and plated onto LB agar. Bacterial invasion was measured using a gentamicin protection assay; after PBS wash, infected J82 cells were incubated in DMEM with 10\% FBS and $100 \mu \mathrm{g} /$ $\mathrm{ml}$ gentamicin for $2 \mathrm{~h}$ followed by washing, lysing and bacterial plating as described above. 


\section{Statistics}

For RT-qPCR analysis, pairwise fixed reallocation randomisation test was performed [45]. Data from growth competition, adhesion and invasion assays were analysed by unpaired t tests with two-tailed p-values using GraphPad Prism 5 software.

\section{Additional files}

Additional file 1: Figure S1. Mutants with no growth defect. The standard error of the mean of two independent 24-h growth experiments is shown. The exact $p$-value can be seen Additional file 7: Table S3. Unpaired t tests with two-tailed p-values were performed using GraphPad Prism 5 software. (JPG 1007 kb)

Additional file 2: Figure S2. Mutants with no cell invasion defect. The standard error of the mean of three independent invasion assays are shown, $P>0.05$ (the exact p-value can be seen in Additional file 8: Table S5). Unpaired t tests with two-tailed p-values were performed using GraphPad Prism 5 software. (JPG 3856 kb)

Additional file 3: Figure S3. Muatnts with no cell adhesion defect. The standard error of the mean of three independent invasion assays are shown, $P>0.05$ (the exact $p$-value can be seen in Additional file 9: Table S4). Unpaired t tests with two-tailed p-values were performed using GraphPad Prism 5 software. (JPG 3905 kb)

Additional file 4: Table S6. TMHMM analysis of upregulated hypothetical genes. Gene name of hypothetical genes from Table 5, in parenthesis are the protein BLAST results. (DOCX $13 \mathrm{~kb}$ )

Additional file 5: Table S7. Primers used for lambda Red recombination. Up and Down primers are used when checking placement of the resistance gene. $\mathrm{KO} 1$ and $\mathrm{KO} 1$ are used for PCR of the resistance gene before the knockout reaction. (DOCX 15 kb)

Additional file 6: Table S8. Primers used for quantitative real time RTPCR (DOCX $15 \mathrm{~kb})$

Additional file 7: Table S3. Competitive index p-values. (DOCX $12 \mathrm{~kb}$ )

Additional file 8: Table S5. $P$-values for cell invasion assays. (DOCX $12 \mathrm{~kb}$ )

Additional file 9: Table S4. P-values for cell adhesion assays. (DOCX $12 \mathrm{~kb}$ )

Additional file 10: Table S1. $P$-values for RT-qPCR verification of genes identified by DFI. (DOCX $12 \mathrm{~kb})$

Additional file 11: Table S2. $P$-values for RT-qPCR verification of genes identified by DFl-seq. (DOCX 13 kb)

\section{Acknowledgements}

Not applicable

\section{Funding}

This work was supported by a PhD stipend from the Danish Research Council (Project ID 0601-01432B). The funding body had no role in the design of the study and collection, analysis and interpretation of data and in writing the manuscript.

\section{Availability of data and materia}

DFl-seq data is publicly available at ArrayExpress https://www.ebi.ac.uk/ arrayexpress/ID: E-MTAB-5657.

\section{Authors' contributions}

MM was the main contributor to the experimental work, interpreted the next-generation sequence data and drafted the manuscript. TK performed adhesion and invasion assays. TKD analysed the next-generation sequence data. JMJ, CS and KAK designed experiments and contributed to the writing of the manuscript. All authors read and approved the final manuscript.

\section{Competing interests}

The authors declare that they have no competing interests

Consent for publication

Not applicable

Ethics approval and consent to participate

Not applicable

\section{Publisher's Note}

Springer Nature remains neutral with regard to jurisdictional claims in published maps and institutional affiliations.

\section{Author details}

'Department of Biochemistry and Molecular Biology, University of Southern Denmark, Campusvej 55, 5230 Odense M, Denmark. ${ }^{2}$ Department of Microbiology and Infection Control, Statens Serum Institut, Artillerivej 5, 2300 Copenhagen S, Denmark.

Received: 22 December 2016 Accepted: 12 April 2017

Published online: 24 April 2017

\section{References}

1. Foxman B. Epidemiology of urinary tract infections: incidence, morbidity, and economic costs. Am J Med. 2002;113(Suppl 1A):5S-13S.

2. Foxman B. Urinary tract infection syndromes: occurrence, recurrence, bacteriology, risk factors, and disease burden. Infect Dis Clin North Am. 2014:28:1-13.

3. Anderson GG, Palermo JJ, Schilling JD, Roth R, Heuser J, Hultgren SJ. Intracellular bacterial biofilm-like pods in urinary tract infections. Science. 2003;301:105-7

4. Mulvey MA, Lopez-Boado YS, Wilson CL, Roth R, Parks WC, Heuser J, et al. Induction and evasion of host defenses by type 1-piliated uropathogenic Escherichia coli. Science. 1998:282:1494-7.

5. Mulvey MA, Schilling JD, Hultgren SJ. Establishment of a persistent Escherichia coli reservoir during the acute phase of a bladder infection. Infect Immun. 2001;69:4572-9.

6. Horvath Jr DJ, Li B, Casper T, Partida-Sanchez S, Hunstad DA, Hultgren SJ, et al. Morphological plasticity promotes resistance to phagocyte killing of uropathogenic Escherichia coli. Microbes Infect. 2011;13:426-37.

7. Justice SS, Hung C, Theriot JA, Fletcher DA, Anderson GG, Footer MJ, et al. Differentiation and developmental pathways of uropathogenic Escherichia coli in urinary tract pathogenesis. Proc Natl Acad Sci U S A. 2004;101:1333-8.

8. Khandige S, Asferg CA, Rasmussen KJ, Larsen MJ, Overgaard M, Andersen TE, Møller-Jensen J. DamX Controls Reversible Cell Morphology Switching in Uropathogenic Escherichia coli. MBio. 2016;7(4). doi:10.1128/mBio.00642-16.

9. Mysorekar IU, Mulvey MA, Hultgren SJ, Gordon J. Molecular regulation of urothelial renewal and host defenses during infection with uropathogenic Escherichia coli. J Biol Chem. 2002;277:7412-9.

10. Mobley HL, Donnenberg MS, Hagan EC. Uropathogenic Escherichia coli. EcoSal Plus. 2009:3(2). doi:10.1128/ecosalplus.8.6.1.3.

11. Wu XR, Sun TT, Medina JJ. In vitro binding of type 1-fimbriated Escherichia coli to uroplakins la and Ib: relation to urinary tract infections. Proc Natl Acad Sci U S A. 1996;93:9630-5

12. Conover MS, Ruer S, Taganna J, Kalas V, De GH, Pinkner JS, et al. Inflammation-induced adhesin-receptor interaction provides a fitness advantage to uropathogenic E. coli during chronic infection. Cell Host Microbe. 2016;20:482-92

13. Mobley HL, Jarvis KG, Elwood JP, Whittle DI, Lockatell CV, Russell RG, et al. Isogenic P-fimbrial deletion mutants of pyelonephritogenic Escherichia coli: the role of alpha Gal(1-4) beta Gal binding in virulence of a wild-type strain. Mol Microbiol. 1993:10:143-55.

14. Anderson GG, Goller CC, Justice S, Hultgren SJ, Seed PC. Polysaccharide capsule and sialic acid-mediated regulation promote biofilm-like intracellular bacterial communities during cystitis. Infect Immun. 2010;78:963-75.

15. Chen SL, Hung CS, Xu J, Reigstad CS, Magrini V, Sabo A, et al. Identification of genes subject to positive selection in uropathogenic strains of Escherichia coli: a comparative genomics approach. Proc Natl Acad Sci U S A. 2006;103:5977-82 
16. Dhakal BK, Mulvey MA. The UPEC pore-forming toxin alpha-hemolysin triggers proteolysis of host proteins to disrupt cell adhesion, inflammatory, and survival pathways. Cell Host Microbe. 2012;11:58-69.

17. Smith YC, Rasmussen SB, Grande KK, Conran RM, O'Brien AD. Hemolysin of uropathogenic Escherichia coli evokes extensive shedding of the uroepithelium and hemorrhage in bladder tissue within the first 24 hours after intraurethral inoculation of mice. Infect Immun. 2008;76:2978-90.

18. Guyer DM, Radulovic S, Jones FE, Mobley HL. Sat, the secreted autotransporter toxin of uropathogenic Escherichia coli, is a vacuolating cytotoxin for bladder and kidney epithelial cells. Infect Immun. 2002;70: 4539-46.

19. Mobley HL. Measuring Escherichia coli Gene Expression during Human Urinary Tract Infections. Pathogens. 2016;5(1). doi:10.3390/ pathogens5010007.

20. Alteri CJ, Smith SN, Mobley HL. Fitness of Escherichia coli during urinary tract infection requires gluconeogenesis and the TCA cycle. PLOS Pathog. 2009:5:e1000448.

21. Valdivia RH, Falkow S. Bacterial genetics by flow cytometry: rapid isolation of Salmonella typhimurium acid-inducible promoters by differential fluorescence induction. Mol Microbiol. 1996;22:367-78.

22. Bumann D, Valdivia $\mathrm{RH}$. Identification of host-induced pathogen genes by differential fluorescence induction reporter systems. Nat Protoc. 2007;2:770-7.

23. Bumann D. In vivo visualization of bacterial colonization, antigen expression, and specific T-cell induction following oral administration of live recombinant Salmonella enterica serovar Typhimurium. Infect Immun. 2001; 69:4618-26.

24. Rollenhagen C, Sorensen M, Rizos K, Hurvitz R, Bumann D. Antigen selection based on expression levels during infection facilitates vaccine development for an intracellular pathogen. Proc Natl Acad Sci U S A. 2004;101:8739-44.

25. Nielsen R, Mandrup S. Genome-wide profiling of transcription factor binding and epigenetic marks in adipocytes by ChIP-seq. Methods Enzymol. 2014; 537:261-79.

26. Love Ml, Huber W, Anders S. Moderated estimation of fold change and dispersion for RNA-seq data with DESeq2. Genome Biol. 2014;15:550.

27. Datsenko KA, Wanner BL. One-step inactivation of chromosomal genes in Escherichia coli K-12 using PCR products. Proc Natl Acad Sci U S A. 2000;97: 6640-5.

28. Foxman B. The epidemiology of urinary tract infection. Nat Rev Urol. 2010;7: 653-60.

29. Subashchandrabose S, Hazen TH, Brumbaugh AR, Himpsl SD, Smith SN, Ernst RD, et al. Host-specific induction of Escherichia coli fitness genes during human urinary tract infection. Proc Natl Acad Sci U S A. 2014;111: 18327-32.

30. Hagan EC, Lloyd AL, Rasko DA, Faerber GJ, Mobley HL. Escherichia coli global gene expression in urine from women with urinary tract infection. PLoS Pathog. 2010;6:e1001187.

31. Westermann AJ, Forstner KU, Amman F, Barquist L, Chao Y, Schulte LN, et al. Dual RNA-seq unveils noncoding RNA functions in host-pathogen interactions. Nature. 2016;529:496-501.

32. Valdivia RH, Falkow S. Fluorescence-based isolation of bacterial genes expressed within host cells. Science. 1997;277:2007-11.

33. Brooks T, Keevil CW. A simple artificial urine for the growth of urinary pathogens. Lett Appl Microbiol. 1997;24:203-6.

34. Hull RA, Hull SI. Nutritional requirements for growth of uropathogenic Escherichia coli in human urine. Infect Immun. 1997;65:1960-1.

35. Schoenlein PV, Roa BB, Winkler ME. Divergent transcription of $\mathrm{pdxB}$ and homology between the $\mathrm{pdxB}$ and serA gene products in Escherichia coli K-12. J Bacteriol. 1989;171:6084-92.

36. Snyder JA, Haugen BJ, Buckles EL, Lockatell CV, Johnson DE, Donnenberg MS, et al. Transcriptome of uropathogenic Escherichia coli during urinary tract infection. Infect Immun. 2004;72:6373-81.

37. Russo TA, Carlino UB, Mong A, Jodush ST. Identification of genes in an extraintestinal isolate of Escherichia coli with increased expression after exposure to human urine. Infect Immun. 1999;67:5306-14.

38. Russo TA, Jodush ST, Brown JJ, Johnson JR. Identification of two previously unrecognized genes (guaA and $\arg$ ) important for uropathogenesis. Mol Microbiol. 1996;22:217-29.

39. Jelsbak L, Thomsen LE, Wallrodt I, Jensen PR, Olsen JE. Polyamines are required for virulence in Salmonella enterica serovar Typhimurium. PLoS One. 2012;7:e36149.
40. Withman B, Gunasekera TS, Beesetty P, Agans R, Paliy O. Transcriptional responses of uropathogenic Escherichia coli to increased environmenta osmolality caused by salt or urea. Infect Immun. 2013;81:80-9.

41. Andersen TE, Khandige S, Madelung M, Brewer J, Kolmos HJ, Moller-Jensen J. Escherichia coli uropathogenesis in vitro: invasion, cellular escape, and secondary infection analyzed in a human bladder cell infection model. Infect Immun. 2012;80:1858-67.

42. Keseler IM, Mackie A, Peralta-Gil M, Santos-Zavaleta A, Gama-Castro S, Bonavides-Martinez C, et al. EcoCyc: fusing model organism databases with systems biology. Nucleic Acids Res. 2013;41:D605-12.

43. Koressaar T, Remm M. Enhancements and modifications of primer design program Primer3. Bioinformatics. 2007;23:1289-91.

44. Untergasser A, Cutcutache I, Koressaar T, Ye J, Faircloth BC, Remm M, et al. Primer3-new capabilities and interfaces. Nucleic Acids Res. 2012;40:e115.

45. Pfaffl MW, Horgan GW, Dempfle L. Relative expression software tool (REST) for group-wise comparison and statistical analysis of relative expression results in real-time PCR. Nucleic Acids Res. 2002:30:e36.

\section{Submit your next manuscript to BioMed Central and we will help you at every step:}

- We accept pre-submission inquiries

- Our selector tool helps you to find the most relevant journal

- We provide round the clock customer support

- Convenient online submission

- Thorough peer review

- Inclusion in PubMed and all major indexing services

- Maximum visibility for your research

Submit your manuscript at www.biomedcentral.com/submit

) Biomed Central 